\title{
Effect of Heat Treatment Process and Optimization of Its Parameters on Mechanical Properties and Microstructure of the AlSi11(Fe) Alloy
}

\author{
Aleksandra Jarco *(D) and Jacek Pezda (D) \\ Faculty of Mechanical Engineering and Computer Science, University of Bielsko-Biala, \\ 43-309 Bielsko-Biała, Poland; jpezda@ath.bielsko.pl \\ * Correspondence: ajarco@ath.bielsko.pl
}

Citation: Jarco, A.; Pezda, J. Effect of

Heat Treatment Process and

Optimization of Its Parameters on

Mechanical Properties and

Microstructure of the AlSi11(Fe)

Alloy. Materials 2021, 14, 2391.

https://doi.org/10.3390/ma14092391

Academic Editor:

Krzysztof Karczewski

Received: 7 April 2021

Accepted: 30 April 2021

Published: 4 May 2021

Publisher's Note: MDPI stays neutral with regard to jurisdictional claims in published maps and institutional affiliations.

Copyright: (c) 2021 by the authors. Licensee MDPI, Basel, Switzerland. This article is an open access article distributed under the terms and conditions of the Creative Commons Attribution (CC BY) license (https:/ / creativecommons.org/licenses/by/ $4.0 /)$.

\begin{abstract}
The paper presents the results of study concerning the evaluation of the precipitation hardening parameters (temperatures and times of solution treatment and artificial ageing processes) having an effect on mechanical properties, and the change in the microstructure of the EN ACAlSi11(Fe) alloy. Based on the obtained results and performed statistical analysis, regression equations and the response surface model in the form of spatial and contour plots were determined to illustrate the effects of solution treatment and artificial ageing parameters on the mechanical properties of the investigated alloy. The performed heat treatment had a positive effect on improving the mechanical properties of the alloy versus the initial state. The maximum increase in tensile strength was by $52 \%$, in unit elongation by $56 \%$, in Brinell hardness by $44 \%$ and impact strength by $88 \%$. Furthermore, a favorable change was observed in the microstructure of the investigated alloy, especially regarding eutectic silicon precipitations, which underwent partial spheroidization and coagulation after the heat treatment.
\end{abstract}

Keywords: heat treatment; mechanical properties; Al-Si alloy; solution treatment; artificial ageing

\section{Introduction}

The Al-Si casting alloys (silumins) with the near eutectic chemical composition are characterised by very good castability [1], low casting shrinkage and susceptibility to form concentrated shrinkage cavity [2], as well as good mechanical properties. Furthermore, they are not prone to hot cracking, which allows to produce thin-walled castings with intricate shapes [3].

Iron, which has an adverse effect on alloy plasticity, tensile strength and castability due to the formation of brittle intermetallic phases, is the most common impurity present in Al-Si alloys [4-6]. Depending on alloy temperature and chemical composition, iron can, upon reaching its critical level, form intermetallic phases of different morphology. The most common of these are $\alpha(\mathrm{AlFeSi})$ phase polyhedral crystals in the shape of the so-called Chinese script and $\beta(\mathrm{AlFeSi})$ phase platelets in the shape of needles [7-10]. The critical Fe content in alloy which triggers the formation of the detrimental $\beta(\mathrm{AlFeSi})$ phase is approx. $0.75 \% \mathrm{Fe}$ for $11 \% \mathrm{Si}$ [11]. However, alloys used for high-pressure die casting can contain Fe levels even up to $1.5 \%$, as the increased Fe content in alloy helps to minimize the costs of die-casting mould repair resulting from their use (mould cavity surface wear) [4].

Due to their very good casting parameters, high creep resistance and resistance to corrosion and abrasion, silumins are very popular materials, widely used in various industries. First of all, in the automotive sector, to manufacture heavy duty combustion engine pistons [12], transmission housings [13] and clutch housings, cylinder heads and engine blocks [14], and in the shipbuilding industry, as engine and fitting component castings, especially for components with required high leak-tightness $[15,16]$. 
The disadvantage of near-eutectic silumins is an irregular acicular or platelet-shaped form of eutectic silicon crystal precipitations, occurring especially during slow cooling down from the casting temperature. It conduces to the propagation of cracks under an external stresses [3], which has an adverse effect on the mechanical properties, and above all on the plasticity and impact strength of the alloy [17].

Mechanical properties of castings can be improved through various processes, such as alloy synthesis (adding alloy additives) [18], modification [19,20] and heat treatment [21]. Precipitation hardening, involving the sequence of solution treatment, quenching and natural (T4) or artificial ageing (T6), is the basic heat treatment applied to silumins containing $\mathrm{Cu}$ and/or Mg [22-24].

Typical T6 heat treatment comprises three stages:

- $\quad$ solution heat treatment at temperature close to the eutectic one in order to dissolve certain intermetallic phases rich with $\mathrm{Cu}\left(\mathrm{Al}_{2} \mathrm{Cu}\right)$ and $\mathrm{Mg}\left(\mathrm{Mg}_{2} \mathrm{Si}\right)$ and formed during solidification, homogenization of alloying elements in a solid solution, and the change in morphology of eutectic silicon $[25,26]$,

- $\quad$ rapid cooling, i.e., cooling down to room temperature to obtain a supersaturated solid solution of dissolved atoms and vacancies,

- $\quad$ natural ageing (at room temperature) or artificial ageing (at elevated temperature) $[24,27,28]$ to precipitation from the solution of the finely dispersed and hardened phase.

In primary Al-Si alloys with low copper content, the main ageing products are metastable modifications of the $\mathrm{Mg}_{2} \mathrm{Si}$ phase $\left(\beta^{\prime \prime}\right.$ and $\left.\beta^{\prime}\right)$, while in the Al-Si alloys containing copper, additional precipitations of the metastable phases- $\mathrm{Al}_{2} \mathrm{Cu}\left(\theta^{\prime \prime}\right.$ and $\left.\theta^{\prime}\right)$, $\mathrm{Al}_{2} \mathrm{CuMg}(\mathrm{S})$, and less frequently, a stable phase $\theta$. The precipitation mechanism of intermetallic phases from supersaturated $\alpha(\mathrm{Al})$ solution is the basis for obtaining changes in the mechanical properties. The strengthening of the AlMgSi alloys occurs due to the release of metastable transition phases and formation of stable equilibrium phases [29-32]. The sequence of the ageing treatment based on the formation of the $\mathrm{Mg}_{2} \mathrm{Si}$ phase is as follows:

$$
\alpha \rightarrow \mathrm{GP} \rightarrow \beta^{\prime \prime} \rightarrow \beta^{\prime} \rightarrow \beta\left(\mathrm{Mg}_{2} \mathrm{Si}\right)
$$

where:

$\alpha$-supersaturated solid solution

GP-the Guinier-Preston regions, $\beta^{\prime \prime}$ and $\beta^{\prime}$-metastable transient phases

$\beta\left(\mathrm{Mg}_{2} \mathrm{Si}\right)$ —stable, equilibrium phase

The process commences with formation of spherical GP zones consisting of enrichment of $\mathrm{Mg}$ and Si atoms. Then, GP zones elongate and develop into a coherent acicular-shaped $\beta^{\prime \prime}$ phase. Precipitations of the $\beta^{\prime \prime}$ phase increase with time, becoming partially coherent rods (phase $\beta^{\prime}$ ) and finally incoherent ones, with their matrix in the form of rods or plates (stable $\beta\left(\mathrm{Mg}_{2} \mathrm{Si}\right.$ ) phase). A maximum alloy strength (peak of the ageing) is reached directly before precipitation of incoherent $\beta\left(\mathrm{Mg}_{2} \mathrm{Si}\right)$ plates. Apelian [27] had observed that the release of very fine $\beta^{\prime}\left(\mathrm{Mg}_{2} \mathrm{Si}\right)$ during ageing treatment gave a clear improvement in the mechanical properties, while Shivkumar [33] observed a large quantity of fine $\beta^{\prime \prime}$ phases with $2-5 \mu \mathrm{m}$ in diameter and $10-20 \mu \mathrm{m}$ in length at peak ageing point, and the length of the $\beta^{\prime \prime}$ phase increased as the ageing progressed. Precipitations of the $\beta^{\prime \prime}$ phase can have an Mg:Si ratio equal to 1:1 [30]. The Mg:Si ratio grows through the GP $\rightarrow \beta^{\prime \prime} \rightarrow \beta^{\prime} \rightarrow \beta$ zone sequence, and the composition of these phases results from the effect of concentration of $\mathrm{Si}$ excess after cooling [34]. The Si can be precipitated in the $\alpha(\mathrm{Al})$ matrix after slight over-ageing, when it is present in a slight excess after cooling [35]. It is presumed that a high concentration of excessive $\mathrm{Si}$ after quenching will result in a $\beta^{\prime \prime}$ phase with low $\mathrm{Mg}: \mathrm{Si}$ ratio [36], as a fraction of available $S i$ is then consumed by the $\beta^{\prime \prime}$ phase formation, while the low concentration of Si remains in the solid solution, in the matrix. This concentration is too low for the Si precipitates to be formed during the initial ageing. The composition of metastable $\beta$ precipitations changes with progressing ageing, while $S i$ is released into the matrix and Si precipitates are formed later [37]. The morphology of these precipitates also 
significantly influences the mechanical properties of the alloy. After the T6 heat treatment, a microstructure is realised that is close to ideal for Al-Si alloys: globular particles of the silicon phase uniformly distributed in the aluminum matrix, and the dispersion is hardened by intermetallic compound particles [3]. The appropriate selection of temperatures and times of solution treatment and artificial ageing of the alloy during heat treatment allows to achieve a wide range of mechanical properties.

The purpose of this study was to evaluate the effects of the parameters (i.e., different temperatures and times of solution treatment and artificial ageing processes) of T6 heat treatment, carried out in accordance with the trivalent test plan, on the mechanical properties (tensile strength UTS, unit elongation $E$, hardness $H B S$, impact strength $K C$ ) and microstructure of the EN AC-AlSi11(Fe) alloy.

\section{Materials and Methods}

The study was performed for the near-eutectic EN AC-AlSi11(Fe) alloy, chemical composition of which was determined by spark OES (Table 1).

Table 1. Chemical composition of the EN AC-AlSi11(Fe) alloy, weight percentage.

\begin{tabular}{cccccccccc}
\hline $\mathbf{S i}$ & $\mathbf{F e}$ & $\mathbf{C u}$ & $\mathbf{M n}$ & $\mathbf{M g}$ & $\mathbf{C r}$ & $\mathbf{N i}$ & $\mathbf{Z n}$ & $\mathbf{T i}$ & $\mathbf{A l}$ \\
\hline 10.0 & 0.81 & 0.37 & 0.09 & 0.21 & 0.01 & 0.01 & 0.15 & 0.09 & balance \\
\hline
\end{tabular}

The increased Fe content in this alloy results primarily from its target application for components produced in the die casting process $[18,38]$.

The alloy was melted in an electric resistance furnace. Then, test pieces for mechanical property tests were cast in permanent moulds. The permanent moulds had been heated to $250{ }^{\circ} \mathrm{C}$ prior to pouring; when pouring, the temperature of alloy in the crucible was $720^{\circ} \mathrm{C}$.

Solution treatment and artificial ageing temperature ranges were selected after analysing melting and crystallisation curves obtained by means of the thermal derivative analysis (TDA) method (Figure 1).

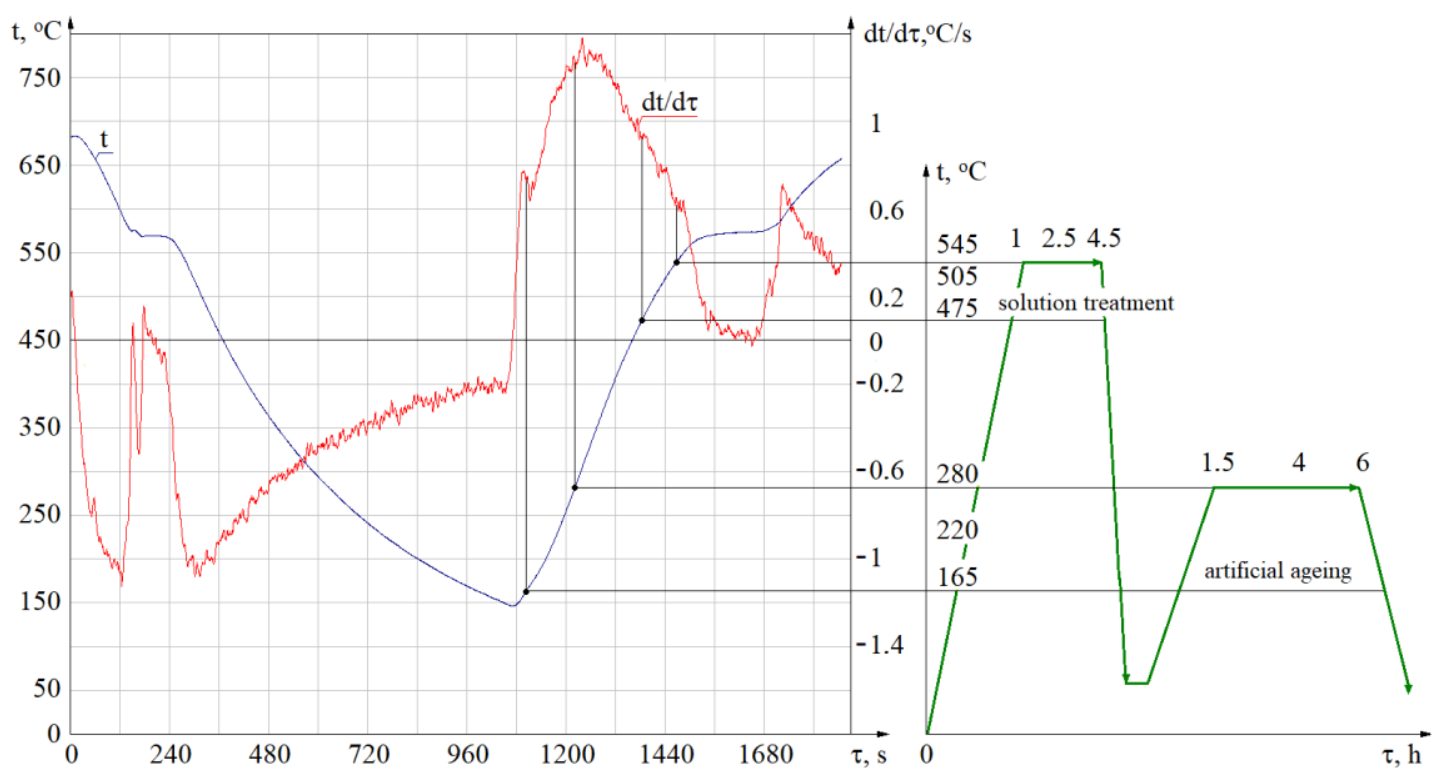

Figure 1. Solution treatment and artificial ageing temperature ranges selected by means of the TDA method.

The times of the individual heat treatment procedures were adopted based on the data provided in the published literature [39-43], bearing in mind the need to limit them for economic reasons. 
Due to the number of input variables, the trivalent test plan was adopted (namely three values for each variable parameter), with four variables (solution treatment and artificial ageing temperatures and times) providing 27 combinations in total (Table 2). For each test plan combination, four repetitions were conducted to calculate average values. Measurement uncertainty was also determined in the form of expanded uncertainty (for $k=2)$.

Table 2. The test piece heat treatment plan.

\begin{tabular}{|c|c|c|c|c|}
\hline \multirow{2}{*}{$\begin{array}{c}\text { Combination } \\
\text { No. }\end{array}$} & \multicolumn{2}{|c|}{ Solution Treatment } & \multicolumn{2}{|c|}{ Artificial Ageing } \\
\hline & Temperature $\left(t_{p}\right),{ }^{\circ} \mathrm{C}$ & Time $\left(\tau_{p}\right), \mathrm{h}$ & Temperature $\left(t_{s}\right),{ }^{\circ} \mathrm{C}$ & Time $\left(\tau_{s}\right), \mathrm{h}$ \\
\hline 1 & & & 165 & 1.5 \\
\hline 2 & & 1 & 220 & 6 \\
\hline 3 & & & 280 & 4 \\
\hline 4 & & & 165 & 6 \\
\hline 5 & 475 & 2.5 & 220 & 4 \\
\hline 6 & & & 280 & 1.5 \\
\hline 7 & & & 165 & 4 \\
\hline 8 & & 4.5 & 220 & 1.5 \\
\hline 9 & & & 280 & 6 \\
\hline 10 & & & 165 & 6 \\
\hline 11 & & 1 & 220 & 4 \\
\hline 12 & & & 280 & 1.5 \\
\hline 13 & & & 165 & 4 \\
\hline 14 & 505 & 2.5 & 220 & 1.5 \\
\hline 15 & & & 280 & 6 \\
\hline 16 & & & 165 & 1.5 \\
\hline 17 & & 4.5 & 220 & 6 \\
\hline 18 & & & 280 & 4 \\
\hline 19 & & & 165 & 4 \\
\hline 20 & & 1 & 220 & 1.5 \\
\hline 21 & & & 280 & 6 \\
\hline 22 & & & 165 & 1.5 \\
\hline 23 & 545 & 2.5 & 220 & 6 \\
\hline 24 & & & 280 & 4 \\
\hline 25 & & & 165 & 6 \\
\hline 26 & & 4.5 & 220 & 4 \\
\hline 27 & & & 280 & 1.5 \\
\hline
\end{tabular}

The solution treatment operation was carried out in the test stand, comprising the electric resistance furnace and the measurement and control equipment connected to a computer recording air temperatures in the furnace chamber and control sample temperatures during heating and holding operations (Figure 2).

Temperature measurements were read every $15 \mathrm{~s}$ using the type $\mathrm{K}(\mathrm{NiCr}-\mathrm{NiAl})$ thermocouple. The control sample temperature was maintained within the range of $\pm 5{ }^{\circ} \mathrm{C}$ from the set value. After solution treatment, the test pieces were cooled in water at $20^{\circ} \mathrm{C}$. Then, artificial ageing was conducted in a laboratory drier SLN 53 STD, with the temperature measurement accuracy of $\pm 3{ }^{\circ} \mathrm{C}$.

After performing individual heat treatment variants (compliant with the Table 2), the test pieces were prepared for tensile strength UTS and unit elongation $E$ testing, in accordance with PN-EN ISO 6892-1:2010 [44]. Initially, the diameter of the parallel length of a circular test piece was $10 \pm 0.03 \mathrm{~mm}$, and the gauge length was $50 \mathrm{~mm}$ [44]. The static tensile tests were performed on the Instron 33R4467 strength testing machine, with $30 \mathrm{kN}$ measuring head, using a $25 \mathrm{~mm}$ extensometer gauge $(0-2.5 \mathrm{~mm}$, resolution $1 \mu \mathrm{m}$, class 1$)$ and the Instron Bluehill 3 software. 


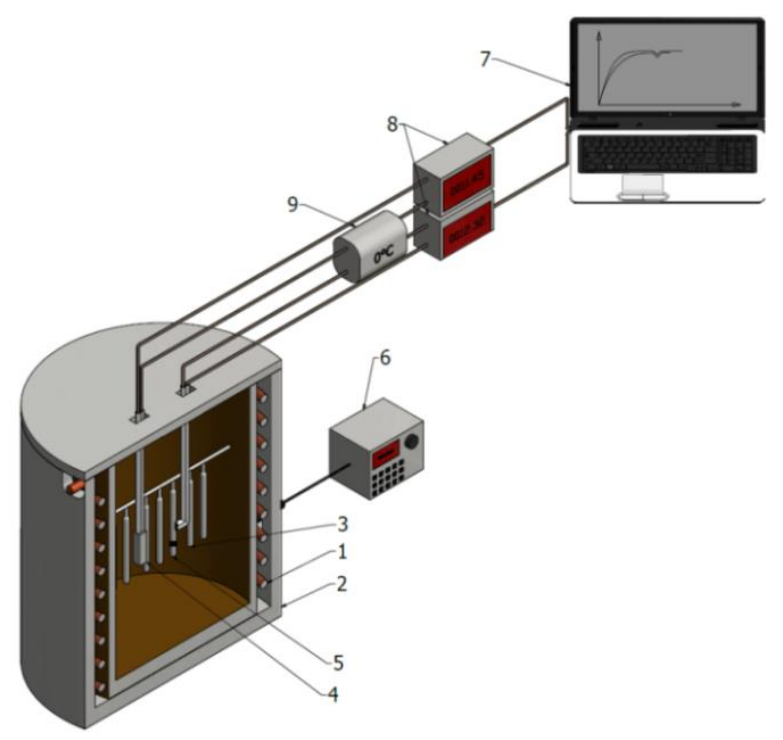

Figure 2. Scheme of the test stand: 1-heating spiral of the furnace; 2 -external shield of the furnace; 3 -test pieces; 4 -thermocouple to measure temperature in the furnace; 5 -test piece with the thermocouple; 6-control system of the furnace; 7-computer storing the results; 8-digital micro-voltmeter of V540, V544 type; 9-thermos.

The hardness was measured using the Brinell method, in accordance with PN-EN ISO 6506:2008 [45,46]. The measurements were performed using an indenter (Ø10 $\mathrm{mm}$ steel ball) under a load of $9807 \mathrm{~N}$ sustained for $30 \mathrm{~s}$.

The impact strength was measured based on the simplified method [47], on the Charpy pendulum machine using notched cylindrical test pieces (Figure 3).

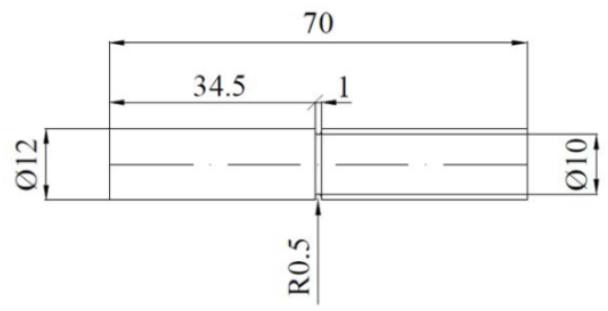

Figure 3. The test piece used for impact strength $K C$ testing by a simplified method (dimensions in millimeters) [47].

Results obtained after T6 heat treatment of the EN AC-AlSi11(Fe) alloy were implemented into a computer software equipped with the Design of Experiments (DOE) module to determine regression coefficients and equations describing the effect of the heat treatment parameters $\left(t_{p}, \tau_{p}, t_{s}, \tau_{s}\right)$ on the mechanical properties (UTS, E, HBS, KC). The most common approximation method of the regression coefficients is the least squares method. The dominant form of the approximating function formed on the basis of the linear model with respect to the function of base is a second-degree algebraic polynomial, with double products constituting so-called interactions. For the independent variables $\left(t_{p}, \tau_{p}, t_{s}, \tau_{s}\right)$ as adopted in the test plan (Table 2), it shall have a function that takes the following general form:

$$
\begin{gathered}
\hat{y}=\hat{\beta}_{1} t_{p}+\hat{\beta}_{2} \tau_{p}+\hat{\beta}_{3} t_{s}+\hat{\beta}_{4} \tau_{s}+\hat{\beta}_{5} t_{p}^{2}+\hat{\beta}_{6} \tau_{p}^{2}+\hat{\beta}_{7} t_{s}^{2}+\hat{\beta}_{8} \tau_{s}^{2}+\hat{\beta}_{9} t_{p} \tau_{p} \\
+\hat{\beta}_{10} t_{p} t_{s}+\hat{\beta}_{11} t_{p} \tau_{s}+\hat{\beta}_{12} \tau_{p} t_{s}+\hat{\beta}_{13} \tau_{p} \tau_{s}+\hat{\beta}_{14} t_{s} \tau_{s}+\hat{\beta}_{15}
\end{gathered}
$$

where:

$\hat{y}$-approximated value of dependent variable (UTS, E, HBS or KC) 
$t_{p}$ - solution treatment temperature, ${ }^{\circ} \mathrm{C}$

$\tau_{p}$-solution treatment time, $\mathrm{h}$

$t_{s}$-artificial ageing temperature, ${ }^{\circ} \mathrm{C}$

$\tau_{s}$-artificial ageing time, $\mathrm{h}$

$\beta_{i}$-regression coefficients $(i=1, \ldots, 15)$

The degree of correlation between the model and the data was determined by the coefficient of determination $R^{2}$ (belongs to $<0,1>$ ). When value of the $R^{2}$ is close or equal to 1 , it can be said that the practically complete variability of the dependent variable is explained by independent variables of the model. The F test, with the Fisher-Snedecor distribution as its theoretical distribution, was used to assess the effect of independent variables on the dependent variable. Furthermore, the hypothesis testing the significance of each partial regression coefficient was verified. The equations presented further in the study include only the variables with significant contribution in the model. The verification of the model also involved the analysis of residual distribution $[48,49]$.

In addition, for the investigated EN AC-AlSi11(Fe) alloy without the heat treatment, the local chemical composition was determined in the spots under the scanning electron microscope (SEM) performed using energy dispersive $\mathrm{x}$-ray spectroscopy (EDS).

\section{Results and Discussion}

\subsection{Ultimate Tensile Strength UTS}

The tensile strength UTS of the raw alloy amounted to $174 \mathrm{MPa}$. After performing the heat treatment of the alloy, it obtained tensile strength UTS ranging from 157 to $265 \mathrm{MPa}$.

The obtained tensile strength UTS testing results (Figure 4) for the individual combinations according to the adopted test plan (Table 2) versus the initial state (W) were collated in the form of bar charts.

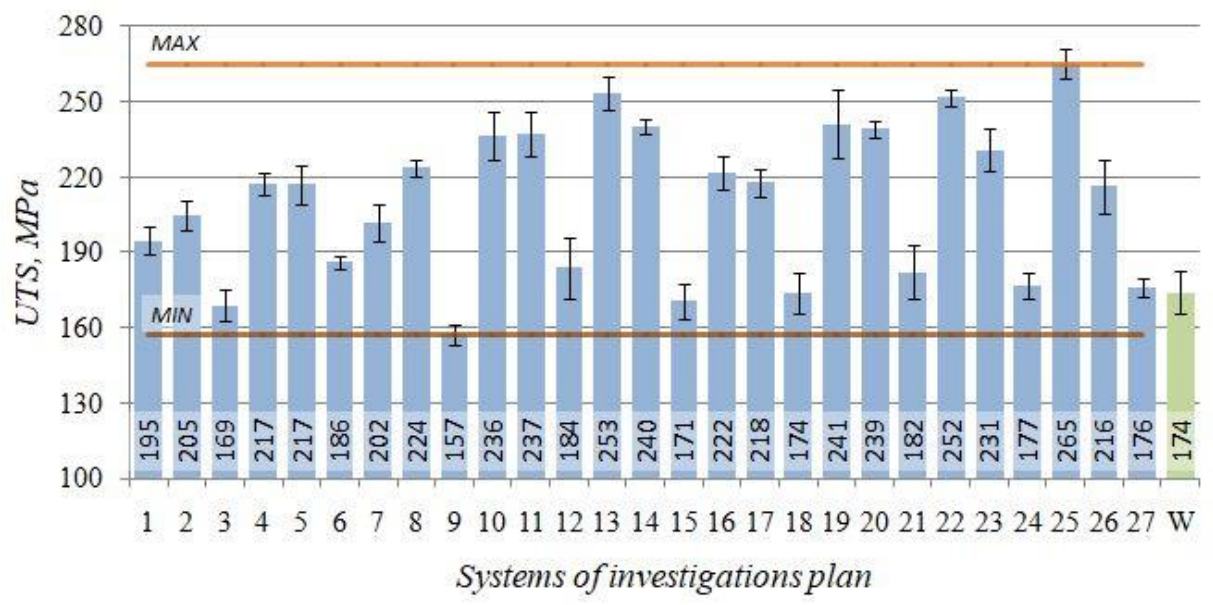

Figure 4. Tensile strength UTS - the initial state (W) and after T6 heat treatment (1-27) for the EN AC-AlSi11(Fe) alloy.

For the investigated alloy, the highest tensile strength value UTS $=265 \mathrm{MPa}$ was obtained after the heat treatment performed according to the test plan combination no. 25 $\left(t_{p}=545^{\circ} \mathrm{C}, \tau_{p}=4.5 \mathrm{~h}, t_{s}=165^{\circ} \mathrm{C}, \tau_{s}=6 \mathrm{~h}\right)$, which indicates over a $50 \%$ increase versus the alloy state without the heat treatment $(\mathrm{W})$. Moreover, for the test plan combination no. 13 and 22, the UTS values reach over $250 \mathrm{MPa}$, which indicates over a $43 \%$ increase versus the initial state $(\mathrm{W})$ for the shorter time of solution treatment $\left(\tau_{p}=2.5 \mathrm{~h}\right)$.

For comparison, $232 \mathrm{MPa}$ was obtained by authors of the publication [50], solution treatment of the AlSi11alloy was performed for $6 \mathrm{~h}$ at temperatures lower with 25 degrees, and artificial ageing it at $205^{\circ} \mathrm{C}$ for $7 \mathrm{~h}$. Instead, Pedersen [51] had received maximal strength amounting to $260 \mathrm{MPa}$ for the AlSi10Mg alloy as early as after 60 min of solution treatment at $540{ }^{\circ} \mathrm{C}$, and $4 \mathrm{~h}$ of artificial ageing at $150^{\circ} \mathrm{C}$, while a longer time of the treatment 
did not lead to increasing the UTS. Much lower ultimate tensile strength (215-230 MPa) had been received by authors of the study [52] in case of the 314.0 alloy after extension of the solution treatment time to $8 \mathrm{~h}$, reduced solution treatment temperature $\left(510^{\circ} \mathrm{C}\right)$ and after artificial ageing at a temperature of $155-240{ }^{\circ} \mathrm{C}$ for $5 \mathrm{~h}$. Ammar et al. [53] solution treatment the same alloy with addition of $0.4 \% \mathrm{Mg}$ at temperature $495^{\circ} \mathrm{C}$ for $4 \mathrm{~h}$ and quenching in hot water $\left(60^{\circ} \mathrm{C}\right)$, and next, naturally ageing, it had received UTS similar to the one obtained by Pedersen [51]. The introduction of artificial ageing treatment for $5 \mathrm{~h}$, instead of natural ageing, increased the UTS of the alloy to the level of $378 \mathrm{MPa}$ for temperature of $180^{\circ} \mathrm{C}$, and as much as to $401 \mathrm{MPa}$ for temperature $155^{\circ} \mathrm{C}$ [54]. In case of the AlSi10Mg alloy, it had been completed many investigations concerning influence of solution treatment and artificial aging on the microstructures and mechanical properties of SLM-produced AlSi10Mg alloy parts, although in case of this technology, the heat treatment did not allow obtaining acceptable mechanical properties [55]. Commonly used in industrial practice alloys with a lower content of silicon, AlSi7Mg and AlSi9Mg are characterised by the tensile strength after the heat treatment at a level similar to the investigated alloy. Pio [56], in case of the AlSi7Mg alloy, after solution treatment at temperature higher with $25^{\circ} \mathrm{C}$ for $6 \mathrm{~h}$ (artificial ageing at temperature $160^{\circ} \mathrm{C}$ for $6 \mathrm{~h}$ ), obtained UTS $=253.5 \mathrm{MPa}$. The decrease of the artificial ageing temperature to level of $150{ }^{\circ} \mathrm{C}$ and shortening of the ageing time to $4 \mathrm{~h}$, as performed by Pedersen [51], resulted in increase of the UTS to the level of $270 \mathrm{MPa}$, whereas the extension of artificial ageing temperature to $230^{\circ} \mathrm{C}$ and prolongation of its time to $8 \mathrm{~h}$ resulted in a further decrease of the UTS to $210 \mathrm{MPa}$ [57]. However, Dobrzański [58], in case of the AlSi9Mg alloy after solution treatment at temperature $525^{\circ} \mathrm{C}$ and artificial ageing at $150{ }^{\circ} \mathrm{C}$ for $6 \mathrm{~h}$, obtained the ultimate tensile strength amounting to $296 \mathrm{MPa}$. Increasing ageing temperatures with $15^{\circ} \mathrm{C}$ and simultaneously prolonging its time with $10 \mathrm{~h}$ had obtained UTS at the level of $280 \mathrm{MPa}$ [59]. Even a higher tensile strength (320 MPa) was obtained by Pezda [60] by solution treatment of the alloy at temperature $545{ }^{\circ} \mathrm{C}$ for $1.5 \mathrm{~h}$, and ageing it at temperature $180^{\circ} \mathrm{C}$ for $8 \mathrm{~h}$.

To illustrate the effect of the heat treatment parameters on tensile strength UTS, the regression equation was determined, which takes the form of the relation (2), for which the coefficient of determination of the reduced model is $R^{2}=0.92$. The statistical significance of the regression equation is $\tau=0.05$, as $F_{(11 ; 69) \text { calc }}=78.44>1.93=F_{(0.05 ; 11 ; 69)}$. The distribution of the residuals is close to normal; it can be assumed on this basis that the correlation between the model and the empirical data is very good.

$$
\begin{aligned}
\hat{y}_{U T S}= & 8.49372 t_{p}+46.96824 \tau_{p}+5.08858 t_{s}-0.0069 t_{p}^{2}-2.6251 \tau_{p}^{2} \\
- & 0.00627 t_{s}^{2}-0.05412 t_{p} \tau_{p}-0.00487 t_{p} t_{s}+0.02548 t_{p} \tau_{s} \\
& -0.02756 \tau_{p} t_{s}-0.06246 t_{s} \tau_{s}-2583.44376[\mathrm{MPa}]
\end{aligned}
$$

The relation (2) allowed to present the effect of temperatures and times of solution treatment and artificial ageing on tensile strength UTS in the form of 3D and contour graphs (Figure 5).

Parameters of the heat treatment process have very significant influence on change of the UTS. Temperature of the solution treatment should be within range of $510-540{ }^{\circ} \mathrm{C}$, while the artificial ageing temperature should be below $200{ }^{\circ} \mathrm{C}$. Increasing the solution treatment temperature caused grain growth and the insoluble phases aggregated and coarsened, resulting in an enhancement of tensile strength [61], while low solution treatment temperature enables obtaining a large amount of homogeneously distributed phases, dispersing and hardening the alloy. 
(a)

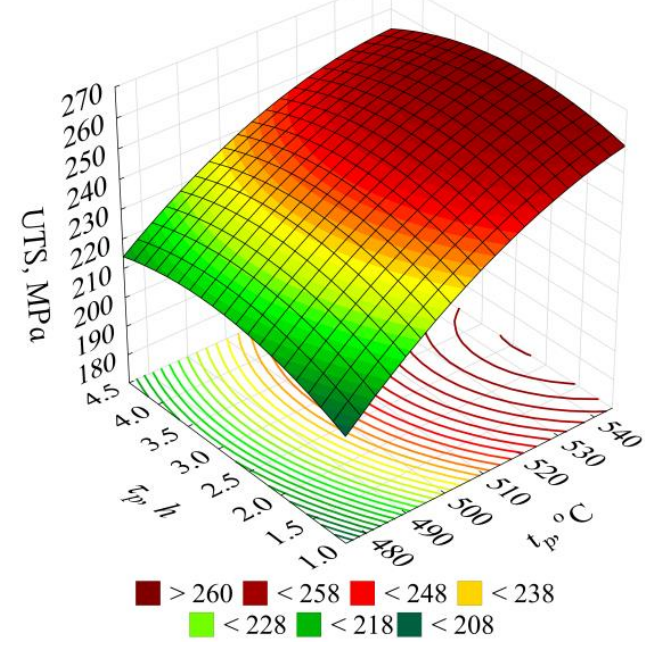

(b)

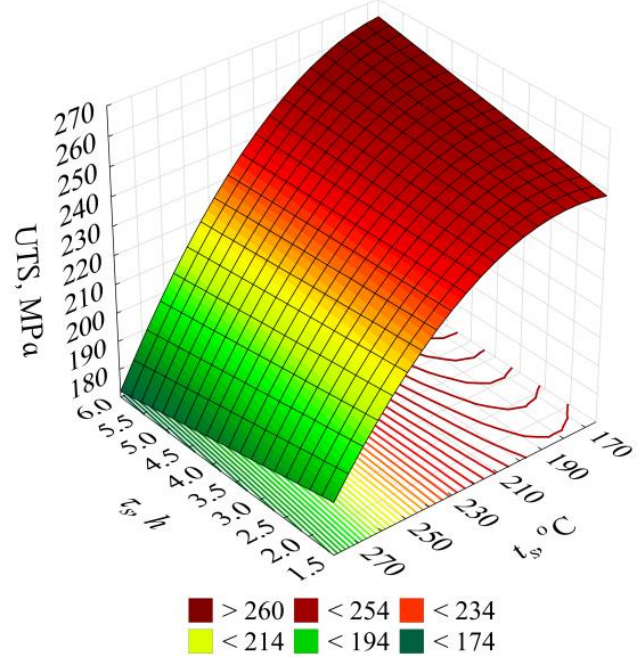

Figure 5. Effects of the T6 heat treatment parameters on tensile strength UTS of the EN AC-AlSi11(Fe) alloy for determined (a) $t_{s}=165^{\circ} \mathrm{C}, \tau_{s}=6 \mathrm{~h},(\mathbf{b}) t_{p}=545^{\circ} \mathrm{C}, \tau_{p}=2.5 \mathrm{~h}$.

\subsection{Unit Elongation $E$}

The value of the unit elongation $E$, obtained for the raw alloy amounted to $2.7 \%$, while performed heat treatment that caused the elongation $E$ has been changed within a range of $1.5 \%$ to $4.2 \%$.

The unit elongation $E$ results obtained for the individual combinations according to the adopted test plan (Table 2) versus the initial state (W) are presented in Figure 6.

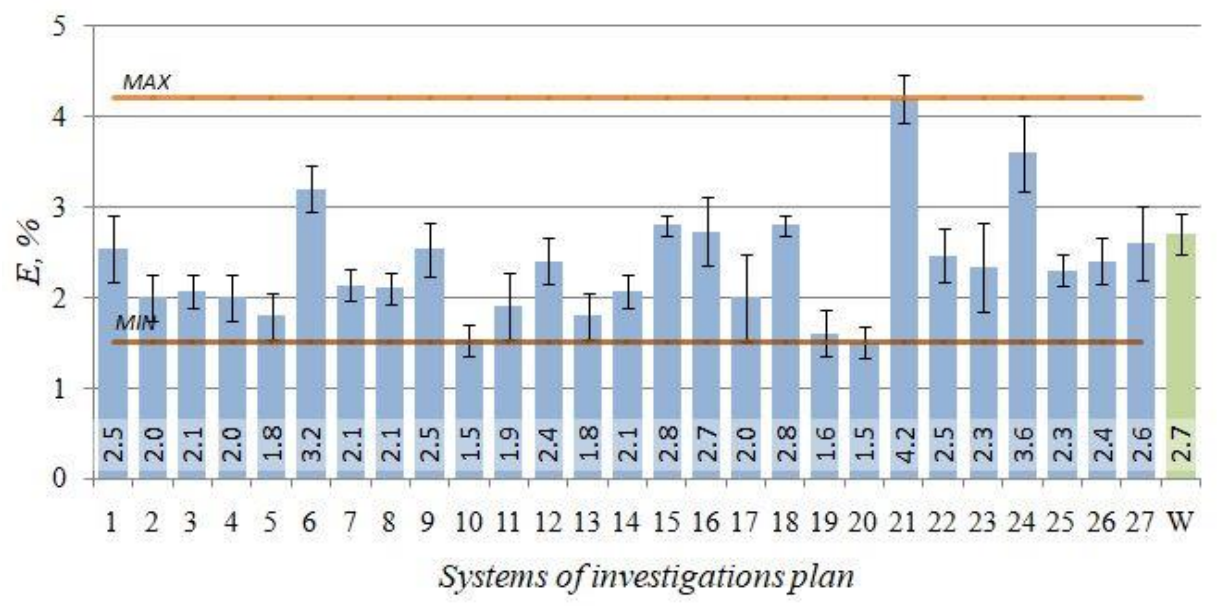

Figure 6. Unit elongation E-the initial state (W) and after T6 heat treatment (1-27) for the EN AC-AlSi11(Fe) alloy.

Alloy unit elongation $E$ reaches the maximum value of $4.2 \%$ after the heat treatment performed as per the test plan combination no. $21\left(t_{p}=545^{\circ} \mathrm{C}, \tau_{p}=1 \mathrm{~h}, t_{s}=280^{\circ} \mathrm{C}, \tau_{s}=6 \mathrm{~h}\right)$ giving an increase by $56 \%$ versus the initial state $(\mathrm{W})$. Similar value of the elongation was received by Pedersen [51] for the AlSi10Mg alloy after solution treatment at temperature lower with $5{ }^{\circ} \mathrm{C}$ and $4 \mathrm{~h}$ artificial ageing at $150{ }^{\circ} \mathrm{C}$. Additionally, $0.4 \mathrm{Mg}$ additive to the 314.0 alloy and its $\mathrm{T} 4$ treatment based on solution treatment at temperature $495{ }^{\circ} \mathrm{C}$ for $4 \mathrm{~h}$, as well quenching in hot water $\left(60^{\circ} \mathrm{C}\right)$ also enables the obtaining of the elongation at the level of $4.4 \%$. Similar elongation (4.5\%) can be also obtained with use of softening annealing, heating the alloy at temperature $370{ }^{\circ} \mathrm{C}$ for $8 \mathrm{~h}$ [62]. 
The elongation within limits of 3\% after T6 treatment of the AlSi9Mg alloy was obtained by Ananthapadmanaban [59] after solution treatment of a casting for $6 \mathrm{~h}$ at temperature $525{ }^{\circ} \mathrm{C}$ and artificial ageing at temperature $165{ }^{\circ} \mathrm{C}$ for $10 \mathrm{~h}$. It is worth to be noticed, that for the AlSi7Mg alloy, shortening of ageing duration from standard $15 \mathrm{~h}$ at temperature $150{ }^{\circ} \mathrm{C}$ to $2 \mathrm{~h}$ at temperature $170^{\circ} \mathrm{C}$, and solution treatment from $4 \mathrm{~h}$ at temperature $535{ }^{\circ} \mathrm{C}$ to $2 \mathrm{~h}$ at temperature $550{ }^{\circ} \mathrm{C}$ enables obtaining $80 \%$ of the maximum elongation $(7 \%)[63,64]$.

The unit elongation $E$ lowest value of $1.5 \%$ was obtained after T6 heat treatment performed according to the test plan combinations no. $10\left(t_{p}=505^{\circ} \mathrm{C}, \tau_{p}=1 \mathrm{~h}, t_{s}=165{ }^{\circ} \mathrm{C}\right.$, $\left.\tau_{s}=6 \mathrm{~h}\right)$ and no. $20\left(t_{p}=545^{\circ} \mathrm{C}, \tau_{p}=1 \mathrm{~h}, t_{s}=220^{\circ} \mathrm{C}, \tau_{s}=1.5 \mathrm{~h}\right)$. This indicates a drop by approximately $45 \%$ versus the initial state $(\mathrm{W})$. Even a lower elongation (not exceeding $1 \%$ ) for the 314.0 alloy with $2 \%$ additive of $\mathrm{Cu}$, as well as without this additive, was obtained by Abdelaziz et al. [52] after solution treatment at similar temperature $\left(510{ }^{\circ} \mathrm{C}\right)$ lasting many times longer $(8 \mathrm{~h})$, however, and artificial ageing at temperatures $155-240{ }^{\circ} \mathrm{C}$ for $5 \mathrm{~h}$. Reduction of solution treatment temperature to $495^{\circ} \mathrm{C}$ and solution treatment time in half (to $4 \mathrm{~h}$ ) with identical parameters of the artificial ageing treatment do not have any effect on improvement of the elongation, which is included within limits of 1.3 to $1.9 \%$ for the alloy without $\mathrm{Cu}$ additive, and below $1 \%$ in case of the alloy with $2 \% \mathrm{Cu}$ additive [54].

From the elongation point of view, artificial ageing at low temperature $\left(150{ }^{\circ} \mathrm{C}\right)$ is also disadvantageous for the AlSi9Mg alloy, reducing it from $8.1 \%$ directly after the solution treatment for $6 \mathrm{~h}$ at $520{ }^{\circ} \mathrm{C}$ to $1.2 \%$ for $3 \mathrm{~h}$ of the artificial ageing, and $2.3 \%$ after $15 \mathrm{~h}$ of the artificial ageing [58].

The relation describing the effect of temperatures and times of solution treatment and artificial ageing processes on the unit elongation $E$ value is expressed by the Equation (3), for which the determination coefficient of the reduced model is $R^{2}=0.78$. The value $F_{(12 ; 68) \text { calc }}=20.19>1.9=F_{(0.05 ; 12 ; 68)}$.

The equation significance is $\tau=0.05$. The distribution of the residual values is close to normal. It can be assumed on this basis that the correlation between the model and the empirical data is good.

$$
\begin{gathered}
\hat{y}_{A_{5}}=-0.178794 t_{p}-0.125144 t_{s}-2.564192 \tau_{s}+0.000137 t_{p}^{2}-0.051481 \tau_{p}^{2} \\
+0.000145 t_{s}^{2}+0.034897 \tau_{s}^{2}+0.001153 t_{p} \tau_{p}+0.000121 t_{p} t_{s}+0.003555 t_{p} \tau_{s} \\
-0.001103 \tau_{p} t_{s}+0.002241 t_{s} \tau_{s}+64.342632[\%]
\end{gathered}
$$

The Equation (3) provided the basis for plotting the response surface graphs (Figure 7), illustrating the effect of T6 heat treatment parameters on the unit elongation E.

Relatively high temperature of the solution treatment (slightly below the eutectic temperature) allows spheroidisation of silicon precipitations and dissolution of strengthening components in the matrix of the alloy, combined with long-lasting artificial ageing at temperature $280^{\circ} \mathrm{C}$ results in the increase of elongation of the alloy, with simultaneous decrease of its strength, which is mainly due to over-ageing of the alloy, i.e., loss of coherence of the phase precipitated with the matrix, and coagulation of precipitated particles of eutectic silicone. 
(a)

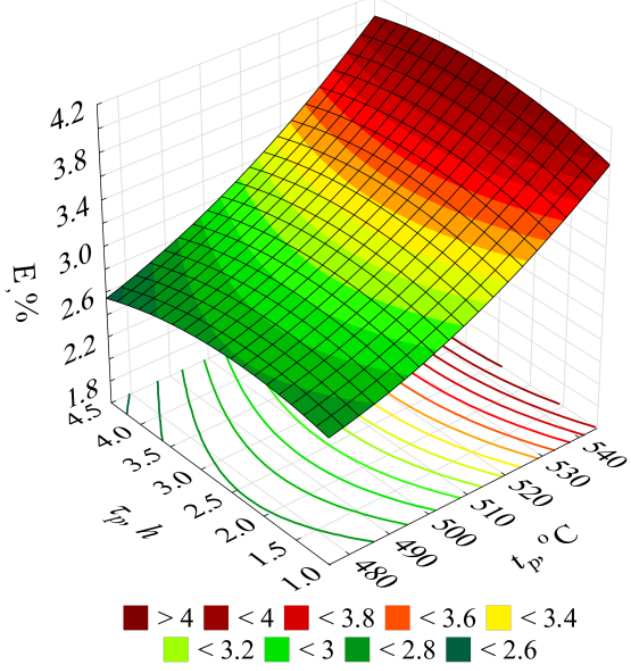

(b)

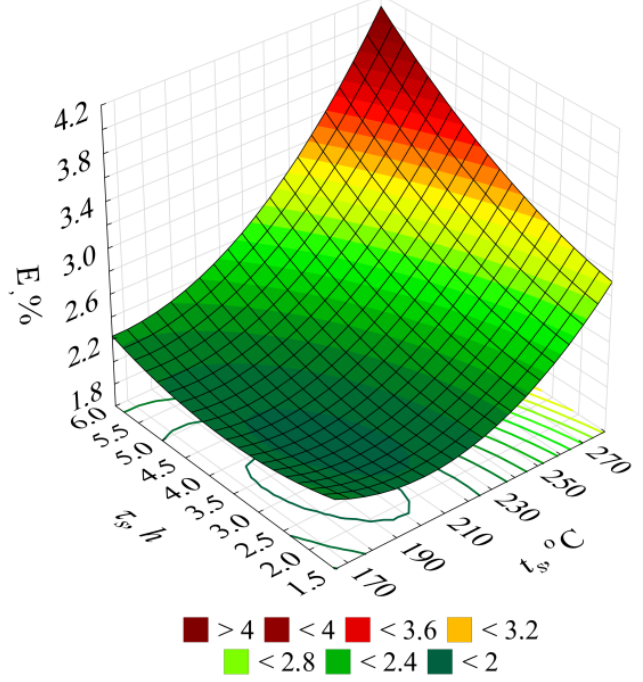

Figure 7. Effects of the T6 heat treatment parameters on unit elongation $E$ of the EN AC-AlSi11(Fe) alloy for determined (a) $t_{s}=280^{\circ} \mathrm{C}, \tau_{s}=6 \mathrm{~h},(\mathbf{b}) t_{p}=545^{\circ} \mathrm{C}, \tau_{p}=2.5 \mathrm{~h}$.

\subsection{Hardness HBS 10/1000/30}

The HBS10/1000/30 hardness of the raw alloy amounted to 72 HBS. After performing heat treatment, the obtained hardness of the alloy was within the range of 56 to 104 HBS.

The obtained results of the EN AC-AlSi11(Fe) alloy hardness HBS for the individual combinations according to the adopted test plan (Table 2) versus the initial state (W) are presented in Figure 8.

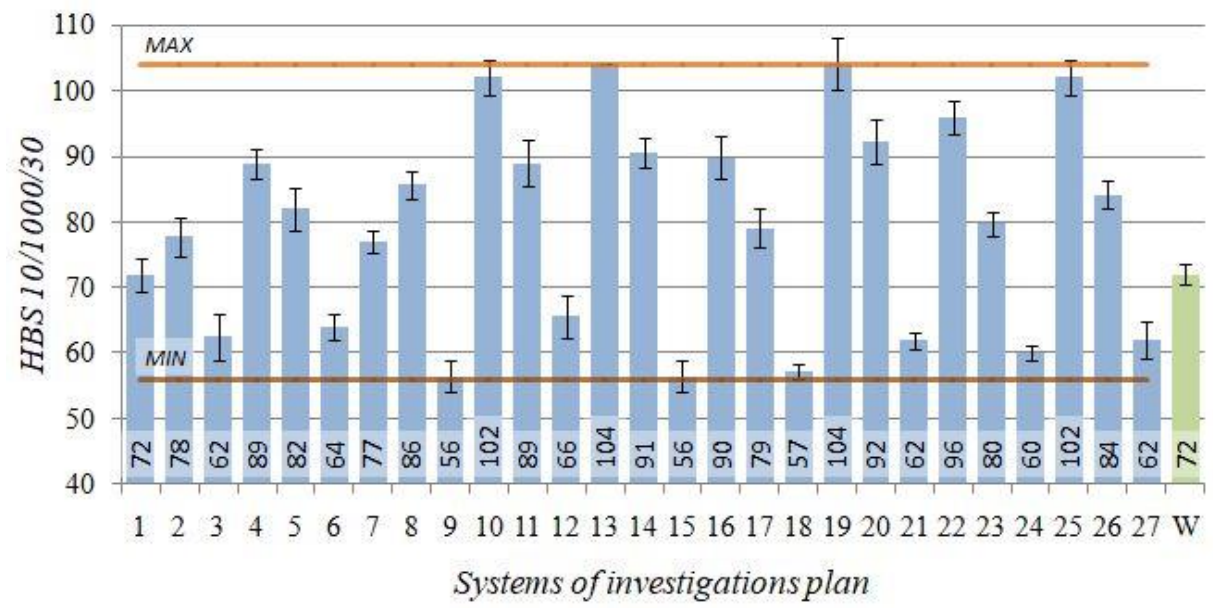

Figure 8. Hardness HBS 10/1000/30 — the initial state (W) and after T6 heat treatment (1-27) for the EN AC-AlSi11(Fe) alloy.

T6 heat treatment of the EN AC-AlSi11 alloy performed according to the test plan combinations no. $13\left(t_{p}=505{ }^{\circ} \mathrm{C}, \tau_{p}=2.5 \mathrm{~h}, t_{s}=165{ }^{\circ} \mathrm{C}, \tau_{s}=4 \mathrm{~h}\right)$ and no. $19\left(t_{p}=545^{\circ} \mathrm{C}\right.$, $\tau_{p}=1 \mathrm{~h}, t_{s}=165^{\circ} \mathrm{C}, \tau_{s}=4 \mathrm{~h}$ ) resulted in the largest increase in hardness $H B S$ (by $44 \%$ ) versus the initial state $(\mathrm{W})$. Increase at similar level (by $42 \%$ ) was obtained in case of the systems no. 10 and 25 , characterised by identical as the systems specified earlier, low ageing temperature at $2 \mathrm{~h}$ longer time of the process.

Hardness at a similar level of $100 \mathrm{HB}$ was obtained by authors of the study [65] for an alloy with similar chemical constitution, solution treatment such alloy for $8 \mathrm{~h}$ at temperature $535^{\circ} \mathrm{C}$ and artificially ageing it at temperature $180^{\circ} \mathrm{C}$ for $3 \mathrm{~h}$. Further prolongation of the 
artificial ageing time resulted in a slight decrease of the hardness to the level 80-90 HB. Furthermore, increase of the artificial ageing temperature to $200{ }^{\circ} \mathrm{C}$ causes reduction of the hardness comparing to the hardness obtained after artificial ageing at $180{ }^{\circ} \mathrm{C}$ within range of solution treatment time from 1 to $24 \mathrm{~h}$ [65]. Similarly as it happened in case of the tensile strength, and also in case of the hardness, the elements from the AlSi10Mg alloy and produced using additive technologies decrease their hardness after standard heat treatment of T6 type [66].

In case of hypoeutectic alloy of the AlSi7Mg, time needed to obtaining the hardness within limits of $100 \mathrm{HB}$ after solution treatment $\left(540^{\circ} \mathrm{C} / 75 \mathrm{~min}\right)$ amounts as much as $10 \mathrm{~h}$ at $170-190{ }^{\circ} \mathrm{C}$ (artificial ageing), while in case of temperature $210{ }^{\circ} \mathrm{C}$, it is only $1 \mathrm{~h}$ [67]. When the temperature increases above $210^{\circ} \mathrm{C}$, a decrease of the strength was observed [67]. According to Tash [68], meanwhile, in case of the 356.0 alloy, both modified and not modified, the hardness increases together with artificial ageing temperature up to $180{ }^{\circ} \mathrm{C}$ (peak temperature); when such temperature is exceeded, a decrease of the hardness occurs at $200{ }^{\circ} \mathrm{C}$ and $220^{\circ} \mathrm{C}$ (overaging of the alloy). In case of the AlSi9Mg alloy, the hardness increases to 80 to $100 \mathrm{BHN}$ during age hardening (solution treatment: $525^{\circ} \mathrm{C} / 10 \mathrm{~h}$; artificial ageing: $\left.165^{\circ} \mathrm{C} / 10 \mathrm{~h}\right)$ [59].

The functional relationship indicating the effect of the heat treatment parameters on hardness HBS 10/1000/30 is described by the Equation (4), for which the coefficient of determination of the reduced model is $R^{2}=0.94$. The significance of the variables in the model is $\alpha=0.05\left(F_{(12,68) \text { calc }}=89.19>1.9=F_{(0.05 ; 12 ; 68)}\right)$. The distribution of the residuals is close to normal. Therefore, it can be assumed that the correlation between the obtained model and the empirical data is very good.

$$
\begin{gathered}
\hat{y}_{H B S}=4.13581 t_{p}+23.38913 \tau_{p}+2.26404 t_{\mathrm{s}}+11.58118 \tau_{s}-0.00322 t_{p}^{2} \\
-0.33952 \tau_{p}^{2}-0.00214 t_{s}^{2}-0.20903 \tau_{s}^{2}-0.03927 t_{p} \tau_{p}-0.00284 t_{p} t_{s} \\
-0.68340 \tau_{p} \tau_{s}-0.03853 t_{s} \tau_{s}-1268.14363[H B S 10 / 1000 / 30]
\end{gathered}
$$

The 3D and contour graphs (Figure 9), obtained on the basis of the Equation (4), show how the hardness HBS values evolve depending on the T6 heat treatment parameters, namely temperatures and times of solution treatment and artificial ageing.

(a)

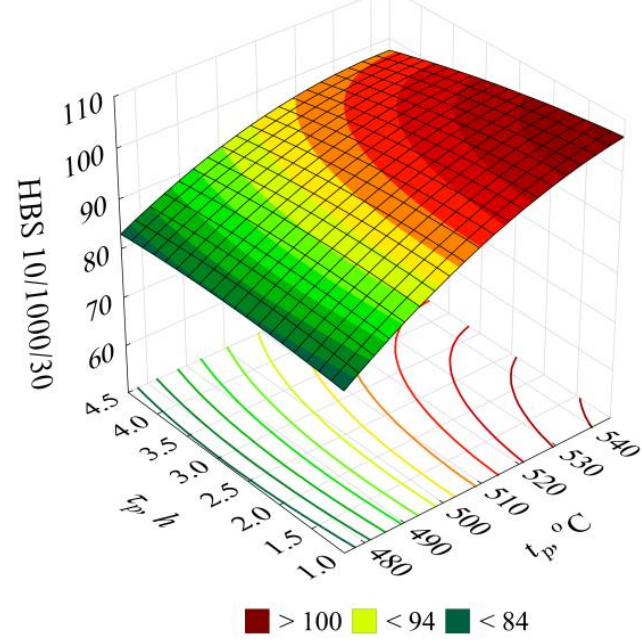

(b)

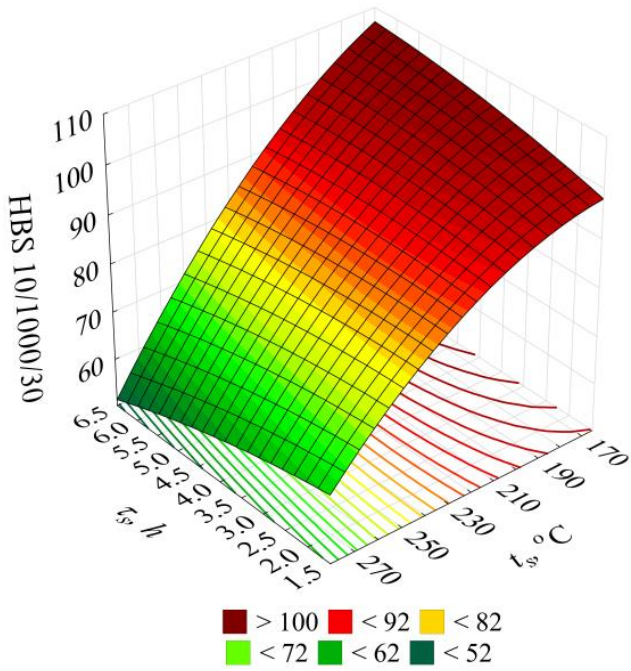

Figure 9. Effects of the T6 heat treatment parameters on hardness HBS 10/1000/30 of the EN ACAlSi11(Fe) alloy for determined (a) $t_{s}=165^{\circ} \mathrm{C}, \tau_{s}=4 \mathrm{~h},(\mathbf{b}) t_{p}=545^{\circ} \mathrm{C}, \tau_{p}=2.5 \mathrm{~h}$.

In case of the hardness, similarly like in case of the tensile strength, the main role is played by high temperature of the solution treatment $\left(20-30{ }^{\circ} \mathrm{C}\right.$ below the eutectic temperature) and low artificial ageing treatment temperature $\left(165^{\circ} \mathrm{C}\right)$ responsible for 
suitable dispersion degree of precipitations strengthening the alloy. The decrease in the hardness values after the T6 heat treatment can also result from the wide dispersion of eutectic silicon particles [50]. Moreover, according to Iskah et al. [69] area of widely dispersed particles of the silicon is smaller, from its availability for the measuring the intended point of view, comparing to the area of the soft phase $\alpha(\mathrm{Al})$, which results in the lower values of the hardness of the test piece.

\subsection{Impact Strength KC}

The impact strength of the raw alloy amounted to $5.7 \mathrm{~J} / \mathrm{cm}^{2}$. The impact strength of the alloy after the heat treatment was included within the range from 4.5 to $10.7 \mathrm{~J} / \mathrm{cm}^{2}$.

The obtained impact strength $K C$ testing results for the test pieces after heat treatment versus the initial state (W) are presented in Figure 10.

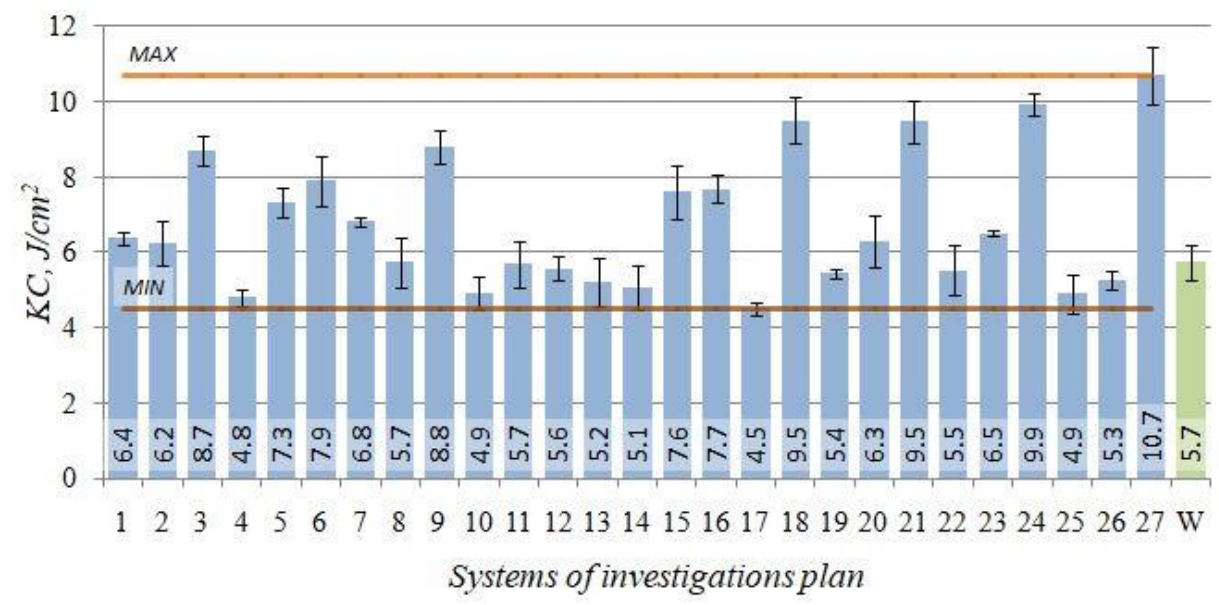

Figure 10. Impact strength $K C$ - the initial state $(\mathrm{W})$ and after T6 heat treatment (1-27) for the EN AC-AlSi1(Fe) alloy.

For the investigated alloy, the impact strength $K C$ maximum value of $10.7 \mathrm{~J} / \mathrm{cm}^{2}$ was obtained after the heat treatment performed according to the test plan combination no. 27 $\left(t_{p}=545{ }^{\circ} \mathrm{C}, \tau_{p}=4.5 \mathrm{~h}, t_{s}=280{ }^{\circ} \mathrm{C}, \tau_{s}=1.5 \mathrm{~h}\right)$. It is the increase by approximately $88 \%$ versus the initial state $(\mathrm{W})$ of impact strength. The increase above $70 \%$ relative to the raw alloy was observed for the systems nos. 18, 21, 24 characterised by the longer time of the artificial ageing, and the equally high (as the system no. 27) temperature of the ageing.

In practice, available literature does not deal with topics of an effect of parameters of the T6 heat treatment on impact strength of the investigated alloy. Authors of the publications, except presented results, had also performed studies in range of soft annealing treatment of investigated alloys, which had given increase of the impact strength in case of a raw alloy at a level of $4.5 \mathrm{~J} / \mathrm{cm}^{2}$ to $6.7-7.7 \mathrm{~J} / \mathrm{cm}^{2}$ after heating of the material at temperature $370{ }^{\circ} \mathrm{C}$ for 5 and $8 \mathrm{~h}$, respectively [70]. Additionally, the studies [71] performed for the AlSi7Mg alloy show that for the solution treatment performed at temperature $545{ }^{\circ} \mathrm{C}$ for $1 \mathrm{~h}$ and artificial ageing carried out at $280^{\circ} \mathrm{C}$ for $5 \mathrm{~h}$, it is possible to generate the impact strength of the order $13 \mathrm{~J} / \mathrm{cm}^{2}$. Meanwhile, in case of a higher temperatures of the artificial ageing amounting to $325{ }^{\circ} \mathrm{C}$ (time: $2 \mathrm{~h}$ ), the value of the impact strength increases to $27 \mathrm{~J} / \mathrm{cm}^{2}$ (making solution treatment at $550{ }^{\circ} \mathrm{C}$ for $3 \mathrm{~h}$ ), the lowest values of the impact strength (about $5 \mathrm{~J} / \mathrm{cm}^{2}$ ) were obtained for low temperatures and long lasting time of artificial ageing $\left(165^{\circ} \mathrm{C}\right.$ for $\left.8 \mathrm{~h}\right)$ [71]. In case of the AlSi9Mg alloy, solution treatment at temperatures $530-550{ }^{\circ} \mathrm{C}$ for 1.5 to $3 \mathrm{~h}$ and artificial ageing at temperatures above $280{ }^{\circ} \mathrm{C}$ for 10-12 h allows obtaining of the impact strength at the level $23-25 \mathrm{~J} / \mathrm{cm}^{2}$. Instead, a decrease of the artificial ageing temperature to the level of $160{ }^{\circ} \mathrm{C}$ drastically reduces its impact strength [60]. 
The effect of temperatures and times of individual heat treatment procedures on the impact strength $K C$ is defined by Equation (5), for which the coefficient of determination of the reduced model is $R^{2}=0.83$. The statistical significance of the regression equation is $\alpha=0.05\left(F_{(9 ; 71) \text { calc }}=37.54>2.1=F_{(0.05 ; 9 ; 71)}\right)$. The distribution of the residuals is close to normal. It can be assumed on this basis that the correlation between the model and the empirical data is good.

$$
\begin{gathered}
\hat{y}_{K C}=-0.75609 t_{p}-0.292353 t_{\mathrm{s}}+0.000694 t_{p}^{2}+0.000396 t_{s}^{2}-0.097927 \tau_{s}^{2} \\
+0.000229 t_{p} t_{s}+0.003009 \tau_{p} t_{s}-0.132103 \tau_{p} \tau_{s}+0.004554 t_{s} \tau_{s}+227.468173\left[\frac{\mathrm{J}}{\mathrm{cm}^{2}}\right]
\end{gathered}
$$

The relation (5) allowed to illustrate the effect of T6 heat treatment parameters on the alloy impact strength $K C$ in the form of 3D and contour graphs (Figure 11).

(a)



(b)

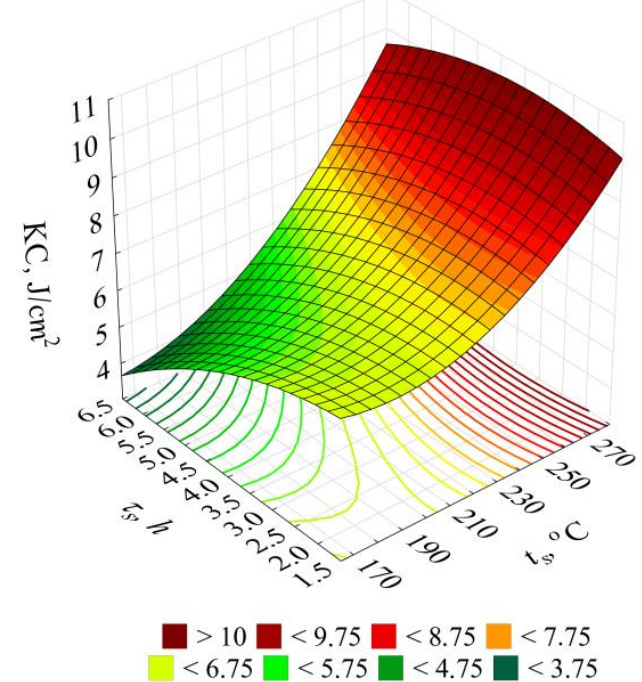

Figure 11. Effects of the T6 heat treatment parameters on impact strength $\mathrm{KC}$ of the EN AC-AlSi11(Fe) alloy for determined (a) $t_{s}=280^{\circ} \mathrm{C}, \tau_{s}=5 \mathrm{~h},(\mathbf{b}) t_{p}=545^{\circ} \mathrm{C}, \tau_{p}=2.5 \mathrm{~h}$.

\subsection{Energy Dispersive X-ray Spectroscopy_EDS}

For the selected microarea of the initial alloy (Figure 12a), the local chemical composition was examined in the spot by the energy dispersive x-ray spectroscopy (EDS) method. Microanalysis results were shown in the form of EDS spectrum. An example sample EDS spectrum (EDS Spot 1 and EDS Spot 2) image is shown in Figure 12b,c.

The analysis of the selected EN AC-AlSi11 alloy microarea microstructure (Figure 12a), EDS spectra and the chemical composition (Table 3) allowed to identify the phase components marked as EDS Spot 1-EDS Spot 6. Table 3 lists the quantitative chemical composition of the EDS-analysed microareas.

The spots marked as EDS Spot 4 and EDS Spot 5 indicate the $\alpha(\mathrm{Al})$ phase. The EDS Spot 2 is the $\alpha(\mathrm{Al})+\beta(\mathrm{Si})$ eutectic precipitation. EDS analysis also showed the presence of Fe-rich phases in the microarea structure-EDS Spot 1, EDS Spot 3 and EDS Spot 6. The spots marked as EDS Spot 3 and EDS Spot 6 indicate precipitations of the intermetallic $\beta(\mathrm{AlFeSi})$ phase, which occurs in the form of long platelet-shaped, acicular precipitations visible in the alloy microstructure (Figure 12a). $\beta(\mathrm{AlFeSi}$ ) phase has an adverse effect on alloy castability [72], causing a drop in tensile strength, plasticity and impact strength [5,6,73], and it conduces to the initiation of cracks [10] and porosity [74], as well as worsening machinability [75]. The EDS Spot 1 is also an Fe-rich intermetallic phase. This precipitation morphology, visible in the microstructure in the shape of the so-called Chinese script (Figure 12a), enables identifying it as the $\alpha(\mathrm{AlFeSi})$ phase, which occurs 
during eutectic solidification [76]. Due to its dense morphology, the $\alpha(\mathrm{AlFeSi})$ phase is not as harmful to the alloy mechanical properties as the $\beta(\mathrm{Al} 5 \mathrm{FeSi})$ phase [77-82].

(a)

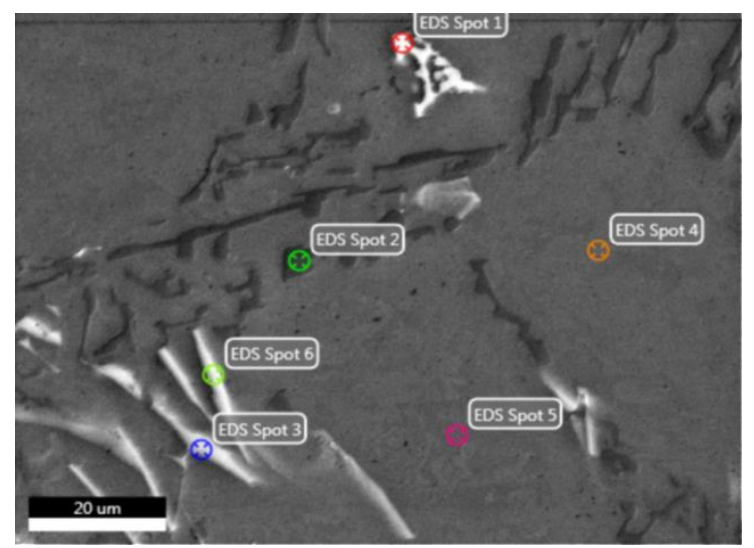

(b)



(c)

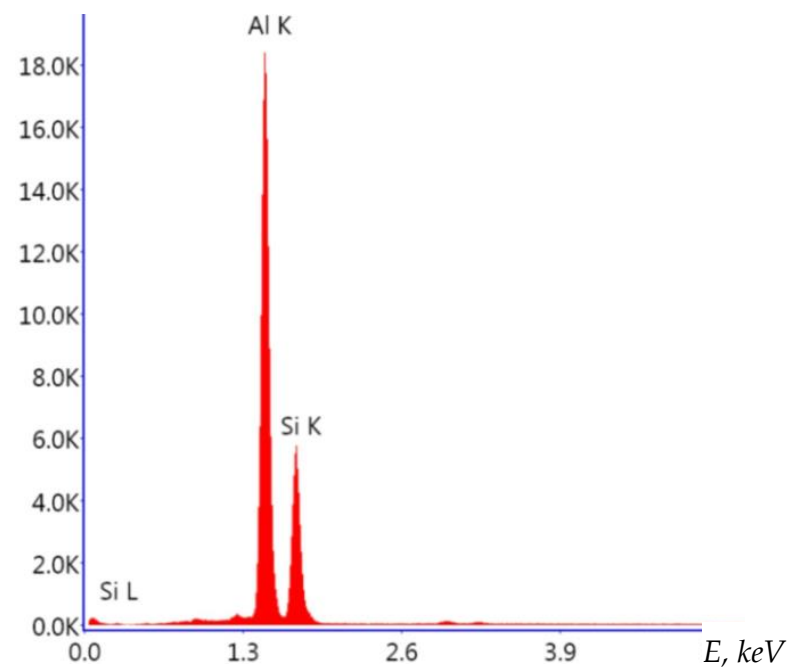

Figure 12. (a) EN AC-AlSi11 alloy microstructure in the initial state with marked EDS-analysed microareas. Images of the (b) EDS Spot 1, (c) EDS spot 2 microareas EDS spectrum. 
Table 3. EDS-determined quantitative chemical compositions of micro-areas, weight and atomic percentage.

\begin{tabular}{ccccc}
\hline Micro-Area & Al, wt. \%/at. \% & Si, wt. \%/at. \% & Fe, wt. \%/at. \% & Phase \\
\hline EDS Spot 1 & $74.25 / 81.75$ & $8.65 / 9.15$ & $17.11 / 9.10$ & $\alpha(\mathrm{AlFeSi})$ \\
EDS Spot 2 & $59.25 / 60.22$ & $40.75 / 39.78$ & - & $\alpha(\mathrm{Al})+\beta(\mathrm{Si})$ \\
EDS Spot 3 & $64.24 / 70.71$ & $19.54 / 20.67$ & $16.21 / 8.62$ & $\beta(\mathrm{AlFeSi})$ \\
EDS Spot 4 & 100 & - & - & $\alpha(\mathrm{Al})$ \\
EDS Spot 5 & 100 & - & - & $\alpha(\mathrm{Al})$ \\
EDS Spot 6 & $65.42 / 71.73$ & $19.02 / 20.03$ & $15.56 / 8.24$ & $\beta(\mathrm{AlFeSi})$ \\
\hline
\end{tabular}

\subsection{Metallographic Analysis}

The metallographic study was performed to evaluate the microstructure of the investigated EN AC-AlSi11(Fe) alloy. The alloy microstructure in the initial state is shown in Figure 13a. Figure 13b shows the microstructure after the heat treatment performed according to test plan combination no. 9, for which the investigated alloy obtained the lowest values of tensile strength UTS $=157 \mathrm{MPa}$ and hardness: 56 HBS, good impact strength $K C=8.8 \mathrm{~J} / \mathrm{cm}^{2}$ and unit elongation $E=2.5 \%$. The microstructure after the heat treatment performed according to test plan combination no. 13 is shown in Figure 13c. For this combination, tensile strength UTS $=253 \mathrm{MPa}$, hardness: $104 \mathrm{HBS}$ and unit elongation $E=1.8 \%$ and impact strength $K C=5.2 \mathrm{~J} / \mathrm{cm}^{2}$ were obtained. The microstructure after T6 heat treatment performed according to test plan combination no. 25 is shown in Figure $13 \mathrm{~d}$. For these heat treatment parameters, the highest tensile strength UTS $=265 \mathrm{MPa}$, hardness level: $102 \mathrm{HBS}$, unit elongation $E$ of $2.3 \%$ and impact strength $K C$ of $4.9 \mathrm{~J} / \mathrm{cm}^{2}$ were obtained.

(a)

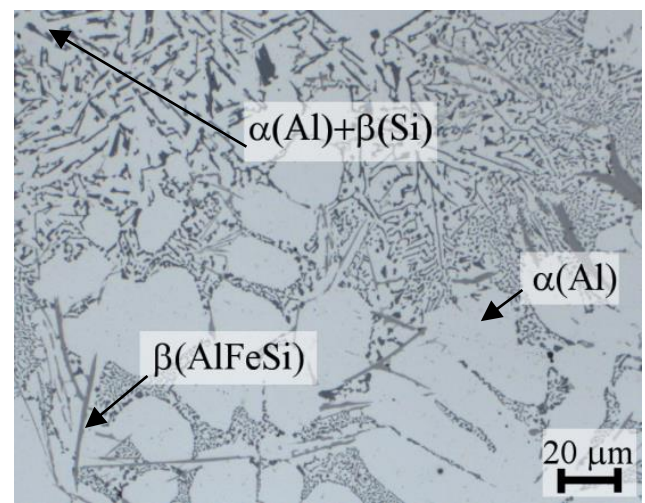

(c)

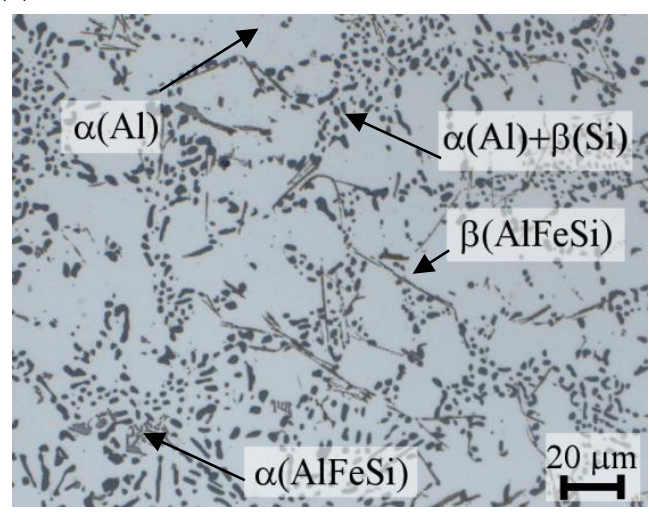

(b)

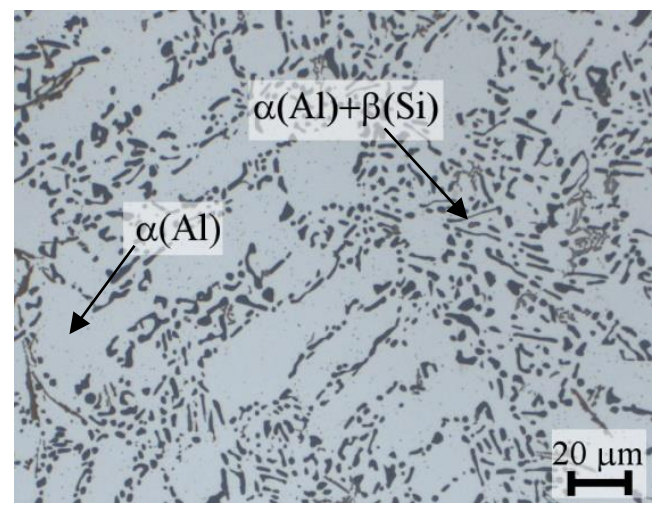

(d)

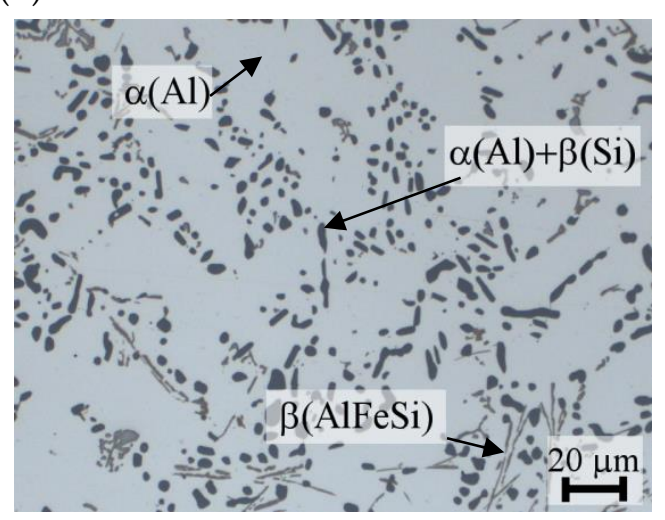

Figure 13. EN AC-AlSi11(Fe) alloy microstructure in the (a) initial state and after T6 heat treatment performed according to the test plan combination nos. (b) $9\left(t_{p}=475{ }^{\circ} \mathrm{C}, \tau_{p}=4.5 \mathrm{~h}, t_{s}=280{ }^{\circ} \mathrm{C}\right.$, $\left.\tau_{s}=6 \mathrm{~h}\right),(\mathbf{c}) 13\left(t_{p}=505{ }^{\circ} \mathrm{C}, \tau_{p}=2.5 \mathrm{~h}, t_{s}=165^{\circ} \mathrm{C}, \tau_{s}=4 \mathrm{~h}\right),(\mathrm{d}) 25\left(t_{p}=545^{\circ} \mathrm{C}, \tau_{p}=4.5 \mathrm{~h}, t_{s}=165^{\circ} \mathrm{C}\right.$, $\left.\tau_{s}=6 \mathrm{~h}\right)$. 
The EN AC-AlSi11(Fe) alloy microstructure in the initial state (Figure 13a) is characterized by the presence of eutectic crystals $\beta$ (Si) (in the form of irregular platelets with sharp edges), which are randomly deposited in the interdendridic spaces of the $\alpha(\mathrm{Al})$ solid solution. The form of the $\alpha(\mathrm{Al})+\beta(\mathrm{Si})$ eutectic can be defined as acicular. Thin, acicular precipitations of the $\beta(\mathrm{AlFeSi})$ phase, which have an adverse effect on the mechanical properties of the alloy (UTS $\left.=174 \mathrm{MPa}, E=2.7 \%, 72 \mathrm{HBS}, K C=5.7 \mathrm{~J} / \mathrm{cm}^{2}\right)$, are also visible. For the investigated alloy, quantity of the manganese equal to $50 \%$ of the iron content was not obtained, which was generally required from transformation of $\beta\left(\mathrm{Al}_{5} \mathrm{FeSi}\right)$ to $\alpha\left(\mathrm{Al}_{15}(\mathrm{Fe}, \mathrm{Mn})_{3} \mathrm{Si}_{2}\right)$ point of view [83]. Heat treatment of the alloy causes a change in its microstructure versus the initial state (Figure 13a). Finely divided dendrites of the $\alpha(\mathrm{Al})$ phase are visible in Figure 13b-d. Eutectic silicon precipitations also underwent visible spheroidization and coagulation. This is due to fragmentation happening first at the joints of the branches or the necks of the $\beta(\mathrm{Si})$ crystals, and then spheroidisation occuring to the fragmented parts, resulting in the formation of elongated or spherical particles [84]. Processes of fragmentation, coagulation and spheroidization, similar to the dissolution, are directly connected with diffusion movements of atoms. Prior solution treatment in the process of the heat treatment, single crystals of $\beta(\mathrm{Si})$ are split to many relatively small crystals, while each of them endeavours to obtain a spherical shape. This allows obtaining the highest level of mechanical properties. Degree of obtaining spherical shape increases with the increase of the heat treatment duration, and simultaneously the process of coagulation is observed, i.e., the thickening of silicon particles. The thermodynamic driving force, which causes changes in morphology of particles, is the tendency to minimize the total Gibbs free energy of the system [3]. Isolated Fe-rich intermetallic phase precipitations are visible against the $\alpha(\mathrm{Al})$ phase background. Thin and acicular precipitations are the $\beta(\mathrm{AlFeSi})$ phase $[78,79,83,85]$, and the Chinese script precipitations are the $\alpha$ (AlFeSi) phase $[9,86,87]$. The minor solubility of iron in $\alpha(\mathrm{Al})$ and acicular morphology of the $\beta(\mathrm{AlFeSi})$ phase cause that, as a rule, they retain their morphology even after long-lasting heating at temperatures close to the solidus equilibrium, causing the deterioration of the strength and plasticity of Al-Si alloy [88,89] castings and initiation of cracks under load [83].

\section{Conclusions}

The purpose of the study was to identify the effects of T6 heat treatment (precipitation hardening) of the EN AC-AlSi11(Fe) alloy by means of determining its mechanical properties (UTS, E, HBS, KC) and to perform a microstructural analysis in the initial state and after T6 heat treatment, according to the trivalent test plan (Table 2) for four variables (temperatures and times of solution treatment and artificial ageing).

On the basis of obtained results, it can be concluded that: the performed heat treatment had a positive effect on a change in the microstructure of the investigated alloy, causing partial spheroidisation and coagulation of eutectic silicon precipitations in comparison with the microstructure of the alloy without the heat treatment. Appropriate selection of the solution treatment and artificial ageing parameters allows for obtaining a several dozen percent increase in the tensile strength, hardness, impact strength and elongation of the AlSi11(Fe) alloy compared to the raw alloy. It is also possible to restrict (to shorten) time of individual operations, which should result in the improved economy of the process. On this basis, it can be concluded that:

- $\quad$ tensile strength UTS reaches a maximum value $(265 \mathrm{MPa})$ after the heat treatment performed for $t_{p}=545^{\circ} \mathrm{C}, \tau_{p}=4.5 \mathrm{~h}, t_{s}=165^{\circ} \mathrm{C}, \tau_{s}=6 \mathrm{~h}$, which gives an increase by $52 \%$ versus the initial value $(174 \mathrm{MPa})$,

- $\quad$ unit elongation $E$ reaches a maximum value (4.2\%) after the heat treatment performed for: $t_{p}=545^{\circ} \mathrm{C}, \tau_{p}=1 \mathrm{~h}, t_{s}=280^{\circ} \mathrm{C}, \tau_{s}=6 \mathrm{~h}$, which gives an increase by $56 \%$ versus the initial value $(2.7 \%)$,

- $\quad$ hardness HBS 10/1000/30 reaches a maximum value (104 HBS) after the heat treatment performed for: $t_{p}=505^{\circ} \mathrm{C}, \tau_{p}=2.5 \mathrm{~h}, t_{s}=165^{\circ} \mathrm{C}, \tau_{s}=4 \mathrm{~h}$ and $t_{p}=545^{\circ} \mathrm{C}, \tau_{p}=1 \mathrm{~h}$, $t_{s}=165{ }^{\circ} \mathrm{C}, \tau_{s}=4 \mathrm{~h}$, which gives an increase by $44 \%$ versus the initial value (72 HBS), 
- $\quad$ impact strength $K C$ reaches a maximum value $\left(10.7 \mathrm{~J} / \mathrm{cm}^{2}\right)$ after the heat treatment performed for $t_{p}=545^{\circ} \mathrm{C}, \tau_{p}=4.5 \mathrm{~h}, t_{s}=280^{\circ} \mathrm{C}, \tau_{s}=1.5 \mathrm{~h}$, which gives an increase by $88 \%$ versus the initial value $\left(5.7 \mathrm{~J} / \mathrm{cm}^{2}\right)$.

The obtained response surface models illustrate a tendency to change the mechanical properties (UTS, E, HBS, KC) of the investigated alloy in the adopted area of the investigations. Depending on change of temperature and time of the solution treatment and artificial ageing can be used for their preliminary prediction, as well as for obtaining required mechanical properties of the alloy resulting from its heat treatment, which is based on the suitable association of parameters of its solution treatment and the artificial ageing process.

Author Contributions: Conceptualization, A.J. and J.P.; methodology, J.P.; software, A.J.; validation, A.J. and J.P., formal analysis, A.J.; study, A.J and J.P.; resources, A.J.; data curation, A.J.; writing —original draft preparation, A.J.; writing—review and editing, A.J and J.P.; visualization, A.J.; supervision, J.P.; project administration, A.J.; and funding acquisition, J.P. All authors have read and agreed to the published version of the manuscript.

Funding: This research received no external funding.

Institutional Review Board Statement: Not applicable.

Informed Consent Statement: Not applicable.

Data Availability Statement: The raw/processed data required to reproduce these findings cannot be shared at this time as the data also forms part of an ongoing study.

Conflicts of Interest: The authors declare no conflict of interest. The funders had no role in the design of the study; in the collection, analyses or interpretation of data; in the writing of the manuscript; or in the decision to publish the results.

\section{References}

1. Di Sabatino, M.; Arnberg, L. Castability of aluminium alloys. Trans. Indian Inst. Met. 2009, 62, 321-325. [CrossRef]

2. Awano, Y.; Morimoto, K. Shrinkage morphology of Al-Si casting alloys. Int. J. Cast Met. Res. 2004, 17, 107-114. [CrossRef]

3. Zolotorevsky, V.S.; Belov, N.A.; Glazoff, M.V. Casting Aluminum Alloys; Elsevier: Oxford, UK, 2007; pp. 327-376.

4. Taylor, J.A. Iron-containing intermetallic phases in Al-Si based casting alloys. Procedia Mater. Sci. 2012, 1, 19-33. [CrossRef]

5. Mathew, J.; Remy, G.; Williams, M.A.; Tang, F.; Srirangam, P. Effect of Fe intermetallics on microstructure and properties of Al-7Si alloys. JOM 2019, 71, 4362-4369. [CrossRef]

6. Williams, S.E.; Tien-Chien, J. Intermetallics formation and their effect on mechanical properties of Al-Si-X alloys. In Intermetallic Compounds_Formation and Applications; Aliofkhazraei, M., Ed.; IntechOpen: London, UK, 2018; pp. 21-41. [CrossRef]

7. Suárez-Peña, B.; Asensio-Lozano, J. Influence of Sr modification and Ti grain refinement on the morphology of Fe-rich precipitates in eutectic Al-Si die cast alloys. Scr. Mater. 2006, 54, 1543-1548. [CrossRef]

8. Hwang, J.Y.; Doty, H.W.; Kaufman, M.J. The effects of Mn additions on the microstructure and mechanical properties of Al-Si-Cu casting alloys. Mater. Sci. Eng. A 2008, 488, 496-504. [CrossRef]

9. Belmares-Perales, S.; Zaldívar-Cadena, A.A. Addition of iron for the removal of the $\beta$-AlFeSi intermetallic by refining of $\alpha$-AlFeSi phase in an Al-7.5Si-3.6Cu alloy. Mater. Sci. Eng. B 2010, 174, 191-195. [CrossRef]

10. Yi, J.Z.; Gao, Y.X.; Lee, P.D.; Lindley, T.C. Effect of Fe-content on fatigue crack initiation and propagation in a cast aluminum-silicon alloy (A356-T6). Mater. Sci. Eng. A 2004, 386, 396-407. [CrossRef]

11. Taylor, J.A. The effect of iron in Al-Si casting alloys. Casting Concepts. In Proceedings of the 35th Australian Foundry Institute National Conference, Adelaide, Australia, 31 October-3 November 2004; pp. 148-157.

12. Manasijevic, S.; Pavlovic-Acimovic, Z.; Raic, K.; Radisa, R.; Kvrgić, V. Optimisation of cast pistons made of Al-Si piston alloy. Int. J. Cast Met. Res. 2013, 26, 255-261. [CrossRef]

13. Pezda, J. Effect of a Selected Heat Treatment Parameters on Technological Quality of a Silumin-Cast Machinery Components; ATH Scientific Publishing House: Bielsko-Biała, Poland, 2014; pp. 77-85.

14. Javidani, M.; Larouche, D. Application of cast Al-Si alloys in internal combustion engine components. Int. Mater. Rev. 2014, 59, 132-158. [CrossRef]

15. Oczoś, K.E.; Kawalec, A. Shaping of Light-Weight Metals; PWN: Warszawa, Poland, 2012; pp. 73-79.

16. PN-EN 1706: Aluminium and Aluminium Alloys-Castings-Chemical Composition and Mechanical Properties; Standards Committee of Poland (PKN): Warsaw, Poland, 2011.

17. Poloczek, Ł.; Kiełbus, A. Influence of technological factors on the quality of aluminum alloys castings. Enterp. Manag. 2016, 19, 14-19. 
18. Szymczak, T.; Gumienny, G.; Klimek, L.; Goły, M.; Szymszal, J.; Pacyniak, T. Characteristics of Al-Si Alloys with high melting point elements for high pressure die casting. Materials 2020, 13, 4861. [CrossRef]

19. Hegde, S.; Prabhu, K.N. Modification of eutectic silicon in Al-Si alloys. J. Mater. Sci. 2008, 43, 3009-3027. [CrossRef]

20. Chen, J.X.; Lu, M.J.; Wu, S.S.; Lü, S.L. Study on eutectic microstructure and modification mechanism of Al-Si alloys. Mater. Sci. Forum 2016, 877, 97-103. [CrossRef]

21. Pezda, J.; Jezierski, J. Non-standard T6 Heat treatment of the casting of the combustion engine cylinder head. Materials 2020, 13, 4114. [CrossRef] [PubMed]

22. Pezda, J. Effect of shortened heat treatment on change of the Rm tensile strength of the 320.0 aluminum alloy. Arch. Foundry Eng. 2015, 15, 75-78. [CrossRef]

23. Mohamed, A.M.A.; Samuel, F.H. A review on the heat treatment of Al-Si-Cu/Mg casting alloys. In Heat Treatment. Conventional and Novel Applications; Czerwinski, F., Ed.; In Tech: London, UK, 2012; pp. 55-72. [CrossRef]

24. Sjölander, E.; Seifeddine, S. The heat treatment of Al-Si-Cu-Mg casting alloys. J. Mater. Process. Technol. 2010, 210, 1249-1259. [CrossRef]

25. Beroual, J.; Boumerzoug, S.; Paillard, Z.; Borjon-Piron, Y. Effects of heat treatment and addition of small amounts of Cu and Mg on the microstructure and mechanical properties of Al-Si-Cu and Al-Si-Mg cast alloys. J. Alloys Compd. 2019, 784, 1026-1035. [CrossRef]

26. Furuta, S.; Kobayashi, M.; Uesugi, K.; Takeuchi, A.; Aoba, T.; Miura, H. Observation of morphology changes of fine eutectic si phase in Al-10\%Si cast alloy during heat treatment by synchrotron radiation nanotomography. Materials 2018, 11, 1308. [CrossRef]

27. Apelian, D.; Shivkumar, S.; Sigworth, G. Fundamental aspects of heat treatment of cast Al-Si-Mg alloys. AFS Trans. 1989, 97, 727-742.

28. Izcara, X.L.; Blank, A.G.; Pyczak, F.; Staron, P.; Schumann, S.; Huber, N. Characterization and modeling of the influence of artificial aging on the microstructural evolution of age-hardenable AlSi10Mg(Cu) aluminum alloys. Mater. Sci. Eng. A 2014, 610, 46-53. [CrossRef]

29. Gupta, A.K.; Lloyd, D.J.; Court, S.A. Precipitation hardening in Al-Mg-Si alloys with and without excess Si. Mater. Sci. Eng. A 2001, 316, 11-17. [CrossRef]

30. Edwards, G.A.; Stiller, K.; Dunlop, G.L.; Couper, M.J. The precipitation sequence in Al-Mg-Si alloys. Acta Mater. 1998, 46, 3893-3904. [CrossRef]

31. Wang, G.Q.; Liu, Y.; Ren, G.C.; Zhao, Z.K. Analyzing Si Precipitation on Age Hardening of an Al-Si-Mg Cast Alloy. Adv. Mater. Res. 2010, 146-147, 1685-1689. [CrossRef]

32. Colley, L.J.; Wells, M.A.; Poole, W.J. Microstructure-strength models for heat treatment of Al-Si-Mg casting alloys I: Microstructure evolution and precipitation kinetics. Can. Metall. Quart. 2014, 53, 125-137. [CrossRef]

33. Shivkumar, S.; Keller, C.; Apelian, D. Ageing behavior in cast Al-Si-Mg alloys. AFS Trans. 1990, 98, 905-911.

34. Maruyama, N.; Uemori, R.; Hashimoto, N.; Saga, M.; Kikuchi, M. Effect of silicon addition on the composition and structure of fine-scale precipitates in Al-Mg-Si alloys. Scripta Mater. 1997, 36, 89-93. [CrossRef]

35. Kaczorowski, M.; Grabski, M.W.; Sawicki, J.; Murza-Mucha, P. A study of precipitation hardening of commercial Al-9 wt\% Si alloy. J. Mater. Sci. 1979, 14, 2781-2786. [CrossRef]

36. Zhang, D.L.; Zheng, L. The quench sensitivity of cast Al-7 wt pet Si-0.4 wt pct Mg alloy. Metall. Mater. Trans. A 1996, $27,3983-3991$. [CrossRef]

37. Eskin, D.G. Decomposition of supersaturated solid solutions in Al-Cu-Mg-Si alloys. J. Mater. Sci. 2003, 38, 279-290. [CrossRef]

38. Jiao, X.; Liu, C.; Guo, Z.; Tong, G.; Ma, S.; Bi, Y.; Zhang, Y.; Xiong, S. The characterization of Fe-rich phases in a high-pressure die cast hypoeutectic aluminum-silicon alloy. J. Mater. Sci. Technol. 2020, 51, 54-62. [CrossRef]

39. Timelli, G.; Lohne, O.; Arnberg, L.; Laukli, H.I. Effect of solution heat treatments on the microstructure and mechanical properties of a die-cast AlSi7MgMn alloy. Metall. Mater. Trans. A 2008, 39A, 1747-1758. [CrossRef]

40. Srivastava, M.C.; Lohne, O. Effects of heat treatment on the microstructure and mechanical properties of ductile AlSi9MgMn die castings. Int. J. Met. 2016, 10, 556-565. [CrossRef]

41. Sjölander, E.; Seifeddine, S. Optimization of solution treatment of cast Al-Si-Cu alloys. Mater. Des. 2010, 31, 44-49. [CrossRef]

42. Sjölander, E.; Seifeddine, S. Artificial ageing of Al-Si-Cu-Mg casting alloys. Mater. Sci. Eng. A 2011, 528, 7402-7409. [CrossRef]

43. Pezda, J. Heat treatment of the EN AC-AlSi9Cu3(Fe) alloy. Arch. Foundry Eng. 2010, 10, 99-102.

44. PN-EN ISO 6892-1:2010: Metallic Materials-Tensile Testing_Part 1: Method of Test at Room Temperature; Standards Committee of Poland (PKN): Warsaw, Poland, 2010.

45. PN-EN ISO 6506-1:2008: Metallic Materials_Brinell Hardness Test_Part 1: Test Method; Standards Committee of Poland (PKN): Warsaw, Poland, 2008.

46. PN-EN ISO 6506-4:2008: Metallic Materials—Brinell Hardness Test. Table of Hardness Values; Standards Committee of Poland (PKN): Warsaw, Poland, 2008.

47. Poniewierski, Z. Crystallization, Structure and Mechanical Properties of Silumins; WNT: Warszawa, Poland, $1989 ;$ pp. $117-118$.

48. Syska, J. Modern Computer Aided Methods of Regression Analysis; Department of Physics, Silesian University: Katowice, Poland, 2014; pp. 13-26.

49. Rabiej, M. Statistics from the Statistica Computer Program; Helion Publishing House: Gliwice, Poland, 2012 ; pp. 126-128. 
50. Vuksanović, D.; Asanović, V.; Šćepanović, J.; Radonjić, D. Effect of chemical composition and T6 heat treatment on the mechanical properties and fracture behaviour of Al-Si alloys for IC engine components. J. Min. Metall. Sect. B Metall. 2021, 14. [CrossRef]

51. Pedersen, L.; Arnberg, L. The effect of solution heat treatment and quenching rates on mechanical properties and microstructures in AlSiMg foundry alloys. Metall. Mater Trans. A 2001, 32, 525-532. [CrossRef]

52. Abdelaziz, M.H.; Samuel, A.M.; Doty, H.W.; Valtierra, S.; Samuel, F.H. Effect of additives on the microstructure and tensile properties of Al-Si alloys. J. Mater. Res. Technol. 2019, 8, 2255-2268. [CrossRef]

53. Ammar, H.R.; Moreau, C.; Samuel, A.M.; Samuel, F.H.; Doty, H.W. Influences of alloying elements, solution treatment time and quenching media on quality indices of 413-type Al-Si casting alloys. Mater. Sci. Eng. A 2008, 489, 426-438. [CrossRef]

54. Ammar, H.R.; Moreau, C.; Samuel, A.M.; Samuel, F.H.; Doty, H.W. Effects of aging parameters on the quality of 413-type commercial alloys. Mater. Des. 2009, 30, 1014-1025. [CrossRef]

55. Wei, L.; Shuai, L.; Jie, L.; Ang, Z.; Yan, Z.; Qingsong, W.; Chunze, Y.; Yusheng, S. Effect of heat treatment on AlSi10Mg alloy fabricated by selective laser melting: Microstructure evolution, mechanical properties and fracture mechanism. Mater. Sci. Eng. A 2016, 663, 116-125. [CrossRef]

56. Pio, L.Y. Effect of T6 heat treatment on the mechanical properties of gravity die cast A356 aluminium alloy. J. Appl. Sci. 2011, 11, 2048-2052. [CrossRef]

57. Lech, Z.; Dudek, P.; Sęk-Sas, G. Instructions for Melting Non-Ferrous Metal Alloys; Instytut Odlewnictwa: Kraków, Poland, 1998; pp. 12-13.

58. Dobrzański, L.A.; Reimann, Ł.; Krawczyk, G. Influence of the ageing on mechanical properties of the aluminium alloy AlSi9Mg. Arch. Mater. Sci. Eng. 2008, 31, 37-40.

59. Ananthapadmanaban, D.; Kurien, G. Silumins: The automotive alloys. Adv. Mater. Process 2012, 170, $28-30$.

60. Pezda, J. Heat treatment of AlSi9Mg alloy. Arch. Foundry Eng. 2008, 8, 169-172.

61. Hao, J.; Yu, B.; Bian, J.; Liu, J.; Sun, W.; Shi, Y.; Li, R. Adjusting the Si phase and forming nanoprecipitation to improve the mechanical properties of Al-Si-Cu-Mg alloy by heat treatment. Adv. Eng. Mater. 2021, 2021, 2001526. [CrossRef]

62. Jarco, A. Improvement of plasticity of the AlSi11 alloy due to soft annealing treatment. Trans. Foundry Res. Inst. 2016, LVI, 261-266. [CrossRef]

63. Peng, J.; Tang, X.; He, J.; Xu, D. Effect of heat treatment on microstructure and tensile properties of A356 alloys. Trans. Nonferrous Met. Soc. 2011, 21, 1950-1956. [CrossRef]

64. Lu, S.-P.; Du, R.; Liu, J.-P.; Chen, L.-C.; Wu, S.-S. A new fast heat treatment process for cast A356 alloy motorcycle wheel hubs. China Foundry 2018, 15, 11-16. [CrossRef]

65. Wiecheć, J.; Uliasz, P.; Knych, T.; Piwowarska-Uliasz, M.; Jarosz, R. The influence of chemical composition and parameters of heat treatment on the mechanical properties and electrical conductivity in hypoeutectic aluminium silicon alloys. Arch. Foundry Eng. 2013, 13, 179-184.

66. Yu, X.; Wang, L. T6 heat-treated AlSi10Mg alloys additive-manufactured by selective laser melting. Procedia Manuf. 2018, 15, 1701-1707. [CrossRef]

67. Rometsch, P.A.; Schaffer, G.B. An age hardening model for Al-7Si-Mg casting alloys. Mater. Sci. Eng. A 2002, 325, 424-434. [CrossRef]

68. Tash, M.; Samuel, F.H.; Mucciardi, F.; Dothy, H.W. Effect of metallurgical parameters on the hardness and microstructural characterization of as-cast and heat-treated 356 and 319 aluminum alloys. Mater. Sci. Eng. A 2007, 443, 185-201. [CrossRef]

69. Ishak, M.; Amir, A.; Hadi, A. Effect of solution treatment temperature on microstructure and mechanical properties of A356 alloy. In Proceedings of the International Conference on Mechanical Engineering Research (ICMER 2013), Bukit Gambang Resort City, Kuantan, Pahang, Malaysia, 1-3 July 2013.

70. Jarco, A. Effect of soft annealing treatment on impact strength and hardness of the EN AC-AlSi11 alloy. Arch. Foundry Eng. 2017, 17, 55-58.

71. Pezda, J.; Jarco, A. Effect of T6 heat treatment parameters on technological quality of the AlSi7Mg alloy. Arch. Foundry Eng. 2016, 16, 95-100. [CrossRef]

72. Mbuya, T.O.; Odera, B.O.; Ng'ang'a, S.P. Influence of iron on castability and properties of aluminium silicon alloys: Literature review. Int. J. Cast Met. Res. 2003, 16, 451-465. [CrossRef]

73. Pancho, A.; Diaz, C.; Sotomayor, O. Influence of Fe on the microstructure and mechanical properties of low Al-SI alloys. Int. J. Microstruct. Mater. Prop. 2018, 13, 317-330. [CrossRef]

74. Závodská, D.; Tillová, E.; Švecová, I.; Chalupová, M.; Kuchariková, L.; Belan, J. The effect of iron content on microstructure and porosity of secondary AlSi7Mg0.3 cast alloy. Period. Polytech. Transp. Eng. 2019, 47, 283-289. [CrossRef]

75. Zedan, Y.; Samuel, F.H.; Samuel, A.M.; Doty, H.W. Effects of Fe intermetallics on the machinability of heat-treated Al-(7-11)\% Si alloys. J. Mater. Process. Technol. 2010, 210, 245-257. [CrossRef]

76. Warmuzek, M. Solidification path of the AlFeMnSi alloys in a stage of primary intermetallic phases precipitation. Trans. Foundry Res. Inst. 2015, 3, 51-60. [CrossRef]

77. Warmuzek, M. Application of an X-ray EDS microanalysis in examination of metals alloy microstructure. J. Foundry Res. Inst. 2000, 3, 3-24.

78. Moustafa, M.A. Effect of iron content on the formation of $\beta-A 15 F e S i$ and porosity in Al-Si eutectic alloys. J. Mater. Process. Technol. 2009, 209, 605-610. [CrossRef] 
79. Terzi, S.; Taylor, J.A.; Cho, Y.H.; Salvo, L.; Suéry, M.; Boller, E.; Dahle, A.K. Nucleation and growth dynamics of the $\alpha-\mathrm{Al} / \beta-\mathrm{Al} 5 \mathrm{FeSi}$ eutectic in a complex Al-Si-Cu-Fe alloy. In Proceedings of the 12th International Conference on Aluminium Alloys, Yokohama, Japan, 5-9 September 2010; pp. 1273-1278.

80. Bacaicoa, I.; Luetje, M.; Wicke, M.; Geisert, A.; Zeismann, F.; Fehlbier, M.; Brueckner-Foit, A. 3D morphology of Al5FeSi inclusions in high Fe-content Al-Si-Cu alloys. Procedia Struct. Integr. 2016, 2, 2269-2276. [CrossRef]

81. Mikołajczak, P.; Ratke, L. Three dimensional morphology of $\beta$-Al5FeSi intermetallics in AlSi alloys. Arch. Foundry Eng. 2015, 15, 47-50. [CrossRef]

82. Samuel, A.M.; Samuel, F.H.; Doty, H.W.; Valtierra, S. Beta Al5FeSi phase platelets-porosity formation relationship in A319.2 type alloys. Inter. Met. 2018, 12, 55-70. [CrossRef]

83. Cao, X.; Campbell, J. Morphology of $\beta-\mathrm{Al}_{5} \mathrm{FeSi}$ phase in Al-Si cast alloys. Mater. Trans. JIM 2006, 47, 1303-1312. [CrossRef]

84. Liu, X.; Beausir, B.; Zhang, Y.; Gan, W.; Yuan, H.; Yu, F.; Esling, C.; Zhao, X.; Zuo, L. Heat-treatment induced defect formation in

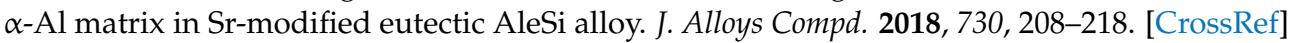

85. Khalifa, W.; Samuel, A.M.; Samuel, F.H.; Doty, W.H.; Valtierra, S. Metallographic observations of $\beta$-AlFeSi phase and its role in porosity formation in Al-7\%Si alloys. Int. J. Cast Met. Res. 2006, 19, 156-166. [CrossRef]

86. Wang, M.; Xu, W.; Han, O. Study of refinement and morphology change of AlFeSi phase in A380 alloy due to addition of Ca, Sr/Ca, Mn and Mn, Sr. Mater. Trans. 2016, 57, 1509-1513. [CrossRef]

87. Gao, T.; Wu, Y.; Li, C.; Liu, X. Morphologies and growth mechanisms of $\alpha$-Al(FeMn)Si in Al-Si-Fe-Mn alloy. Mater. Lett. 2013, 110, 191-194. [CrossRef]

88. Tunçay, T.; Bayoğlu, S. The Effect of Iron Content on Microstructure and Mechanical Properties of A356 Cast Alloy. Metall. Mater. Trans. B 2017, 48, 794-804. [CrossRef]

89. Shabestari, S.G. The effect of iron and manganese on the formation of intermetallic compounds in aluminum-silicon alloys. Mater. Sci. Eng. A 2004, 383, 289-298. [CrossRef] 